CRM D0006868.A1/ Final

September 2002

\title{
Islam in Indonesia's Political
} Future

Prof. Robert W. Hefner 


\section{Report Documentation Page}

Form Approved

OMB No. 0704-0188

Public reporting burden for the collection of information is estimated to average 1 hour per response, including the time for reviewing instructions, searching existing data sources, gathering and maintaining the data needed, and completing and reviewing the collection of information. Send comments regarding this burden estimate or any other aspect of this collection of information,

including suggestions for reducing this burden, to Washington Headquarters Services, Directorate for Information Operations and Reports, 1215 Jefferson Davis Highway, Suite 1204, Arlington

VA 22202-4302. Respondents should be aware that notwithstanding any other provision of law, no person shall be subject to a penalty for failing to comply with a collection of information if it

does not display a currently valid OMB control number.

1. REPORT DATE

SEP 2002
2. REPORT TYPE

4. TITLE AND SUBTITLE

Islam in Indonesia's Political Future

6. $\operatorname{AUTHOR}(\mathrm{S})$

7. PERFORMING ORGANIZATION NAME(S) AND ADDRESS(ES)

CNA Analysis \& Solutions,Center for Naval Analyses ,4825 Mark Center Drive,Alexandria,VA,22311

9. SPONSORING/MONITORING AGENCY NAME(S) AND ADDRESS(ES)
3. DATES COVERED

00-00-2002 to 00-00-2002

5a. CONTRACT NUMBER

5b. GRANT NUMBER

5c. PROGRAM ELEMENT NUMBER

5d. PROJECT NUMBER

5e. TASK NUMBER

5f. WORK UNIT NUMBER

8. PERFORMING ORGANIZATION

REPORT NUMBER

10. SPONSOR/MONITOR'S ACRONYM(S)

11. SPONSOR/MONITOR'S REPORT

NUMBER(S)

12. DISTRIBUTION/AVAILABILITY STATEMENT

Approved for public release; distribution unlimited

13. SUPPLEMENTARY NOTES

14. ABSTRACT

15. SUBJECT TERMS

16. SECURITY CLASSIFICATION OF: a. REPORT

unclassified b. ABSTRACT

unclassified c. THIS PAGE

unclassified
17. LIMITATION OF ABSTRACT

Same as

Report (SAR)
18. NUMBER 19a. NAME OF

OF PAGES

54 
Project Asia is The CNA Corporation's focal point for Asian security studies. This ongoing project's work is contained in several types of products, including: regional assessments, country profiles, occasional papers, monographs, and conferences on important security topics. Project Asia's overall analytic approach seeks to synthesize the work of CNAC researchers, policy analysts, regional experts, and other sources of information with what is being said and written in the region; thus, it can provide the context necessary for policy makers to make decisions relevant to the region. Although the focus is on practical near-term issues, longer-term trends are not neglected.

Project Asia falls under the Center for Strategic Studies of The CNA Corporation (CNAC). The Center for Strategic Studies combines in one organizational entity regional analyses, studies of political-military issues, and strategic and force assessment work. Such a center allows CNAC to join the global community of centers for strategic studies, and share perspectives on major security issues that affect nations. There is a continuing need for analytic and assessment work that goes beyond conventional wisdom. The Center for Strategic Studies is dedicated to providing a deeper level of expertise, and work that considers a full range of plausible possibilities, anticipates a range of outcomes, and does not simply depend on straightline predictions.

While the Center's charter does not exclude any area of the world, Center analysts have clusters of proven expertise in the following areas:

- The full range of East Asian security issues, especially those that relate to China

- Russian security issues, based on ten years of strategic dialogue with Russian institutes

- Maritime strategy

- Future national security environment and forces

- Strategic issues related to the Eastern Mediterranean region

- Missile defense

- Latin America, including guerrilla operations

- Operations in the Persian (Arabian) Gulf.

Project Asia is under the direction of Dr. David Finkelstein, who is available at (703)824-2952 and on e-mail at finked@cna.org. The Center for Strategic Studies is under the direction of Rear Admiral Michael McDevitt, USN (Ret.), who is available at (703)824-2614 and on e-mail at mcdevitm@cna.org. The administrative assistant for Project Asia and the Center is Ms. Brenda Mitchell, who can be reached at (703)824-2137 and on e-mail at mitchelb@cna.org.

Approved for distribution:

September 2002

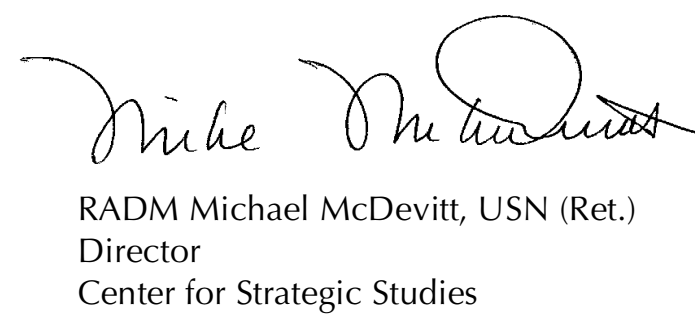

This document represents the best opinion of the authors.

It does not necessarily represent the opinion of the Department of the Navy or The CNA Corporation.

Distribution unlimited. Specific authority: N00014-00-D-0700.

For copies of this document call: CNA Document Control and Distribution Section at 703-824-2943.

\section{Copyright () 2002 The CNA Corporation}




\section{Table of Contents}

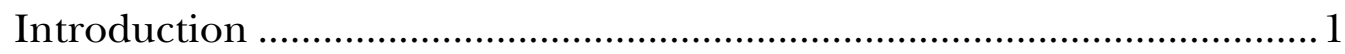

Moderate Islam and the rise of Islamist radicalism ............................... 4

The Islamic resurgence .................................................................. 4

The declining influence of secular nationalism .................................5

The rise of the radical fringe, with an aside on the Saudi role............. 7

The Soeharto regime's outreach to Muslims ....................................... 9

The propagation of conspiracy theories .......................................... 12

Radical Muslims, the armed forces, and Muslim political parties........... 14

The elections of June 1999 illustrated Muslim moderation................ 14

A comparison of the FPI, Laskar Jihad, and Majelis Mujahidin ......... 19

Muslim parties and social organizations .........................................227

The future of the Islamic parties and Golkar ................................. 30

The future of major Muslim social associations................................. 35

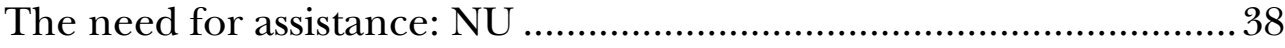

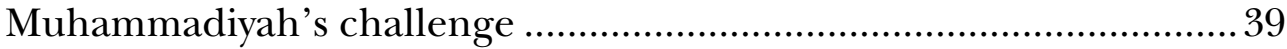

Revitalizing the Islamic university system ................................... 40

Indonesia's relationship with the United States, and regional and

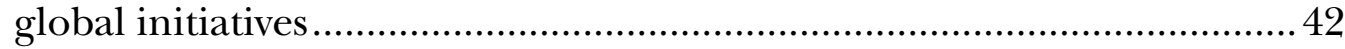

The evidence on Al Qaeda connections ......................................... 43

The need for transnational cooperation against terror and for an

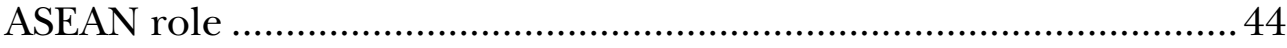

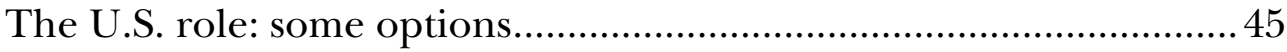




\begin{abstract}
About the author
Robert W. Hefner is Professor of Anthropology and Associate Director of the Institute for the Study of Economic Culture at Boston University. He is currently directing a comparative project for the Pew Charitable Trusts on "Civic Pluralist Islam: Policies and Prospects for a Changing Muslim World," as well as editing the sixth volume of the New Cambridge History of Islam, entitled Muslims and Modernities: Culture and Society in an Age of Western Hegemony. His most recent book is Civil Islam: Muslims and Democratization in Indonesia (Princeton, 2000).
\end{abstract}




\section{Introduction}

Indonesia has vast natural resources, an enormous domestic consumer market, and, although battered since late 1997, one of Asia's largest industrial sectors. It is also the single most powerful country in the influential Association of Southeast Asian Nations (ASEAN). With some 17,000 islands (half of which are inhabited) spread across a territorial expanse equal to that of the continental United States, Indonesia also sits astride some of the most important shipping routes in the world. For these and other reasons, Indonesia is of singular strategic importance to the United States and to our friends and allies in the East Asian region.

With some 88 percent of its 215 million people officially professing Islam, Indonesia also ranks as the largest majority-Muslim country in the world. Since winning independence from the Netherlands in December 1949, Indonesia's political order has been officially based on a system of multi-religious nationalism rather than Islamic law or governance. Muslim political parties have nonetheless played a prominent role in the country's political system. Despite occasional outbreaks of extremism, however, the central current in Indonesian Muslim politics has been moderate. During the 1950s and 1960s, when Indonesia developed the largest Communist Party in the non-Communist world, Muslim leaders looked to the United States as an ally and friend in their struggle against Communism. Attitudes toward the United States cooled slightly in the early 1970s, as Israel's victory in the 1967 war and its occupation of Arab lands colored Muslim perceptions of the United States. Despite these developments, until the early 1980s many in the Muslim community remained lax in their profession of Islam and secular nationalist in their political views.

Beginning in the 1980s, however, Indonesia experienced a historically unprecedented Islamic resurgence. Public expressions of piety increased dramatically, and people once lax in the conduct of religious affairs became observant. Even at the height of the resurgence, however, the predominant political disposition among the Muslim populace remained moderate. There were a few outbreaks of radical extremism in the 1970s and 1980s, and radical Islamist groupings established a foothold on college campuses in the 1990s. But the ranks of the hardliners were more than balanced by Muslims of a pluralist and even pro-democracy disposition. Most of the activists involved in the democracy movement that helped to topple President Soeharto and bring an end to the New Order regime (1966-1998) in May 1998 were Muslim. 
In recent years, however, Islamic extremism has benefited from assistance from unexpected sources. In the final years of his regime, President Soeharto reversed his previous policies on Islam and, rather than repressing Islamic extremism, he courted it. Working with a "green" or Islamist faction in the armed forces command (whose motives had as much to do with service rivalries as religion or ideology), the President opened channels to Islamist radicals in an effort to defend his regime from domestic and western critics. Some observers have suggested that this opening to Islam also served as a counter-weight to the unchallenged power of the military-a military that was beginning to look beyond the Soeharto era.

Although at first discredited by their association with Soeharto, hardline Islamists survived the fall of the Soeharto regime and have expanded their organizations significantly since 1998. They have been most effective at mobilizing support around the issue of alleged threats, domestic and international, to Islam. The more militant groups have developed large paramilitaries, some with the clandestine support of former and active military officials. These militias have threatened to attack Americans, staged actions against alleged centers of vice (discothèques, bars, and brothels), attacked leftwing and democracy activists, and mobilized thousands of Muslim fighters to do battle with Christians in eastern Indonesia. Although the great majority of radicals appear to be home grown, a very few among the paramilitary militants may have developed ties with international terrorist groupings, including $\mathrm{Al}$ Qaeda. Although their overall numbers remain small, the radicals have been able to exercise an influence on Muslim politics vastly out of proportion with their representation in society. Although their influence should not be exaggerated, the radicals represent a serious challenge to the stability of Indonesia and its neighbors, as well as to the interests of the United States.

This report seeks to analyze the role of political Islam in general, and radical Islamism in particular, in Indonesia over the next five to ten years. It does so by examining several key issues:

- The political disposition of the Muslim community as a whole, including domestic and international influences on radical Islamism, and the vulnerability of mainstream groupings to radical appeals;

- The evolving and future relationship of radical Islamism to important domestic actors, especially the Indonesian armed forces (TNI);

- The relationship of Islamist radicals to Islamic political parties and social organizations;

- The future of major Muslim social associations;

- Current and emerging leaders of Indonesian Islamic thought and activity; 
- The impact of trends in Islam on Indonesia's relationship with the United States, Indonesia's neighbors, and regional and global initiatives related to counter-terrorism, regional security, and international bodies.

The conclusion to this report will summarize these trends and attempt to assess their implications for American interests and cooperation with Indonesia. 


\section{Moderate Islam and the rise of Islamist radicalism}

\section{The Islamic resurgence: not anti-American but driven by social and educational change}

To understand the current balance of power among radicals and moderates in the Muslim community, it is helpful to look back a few years. Although for much of their modern history most Indonesian Muslims have been politically moderate and even lax in their profession of the faith, in the 1980s and 1990s Indonesia experienced a historically unprecedented Islamic resurgence. Attendance at Friday mosque prayers and enrollment in religious schools soared. Between 1970 and 1994, the government and private organizations more than doubled the number of mosques and religious schools across the country. For the first time in Indonesian history, large numbers of young women began to wear veils (jilbab, hijab) as a symbol of their piety. On university campuses across the country, Muslim organizations such as the Association of Muslim Students (Himpunan Mahasiswa Islam, or HMI) displaced the secular nationalist student organizations which, up to this time, had dominated university government.

An analysis of the reasons for the resurgence is outside the charge of this report, but, for policy purposes, two points should be noted. First, the primary influence on the resurgence in this early period had little to do with radical politics or anti-Americanism, but reflected broader social changes in Indonesian society. The most important changes included urban growth, the development of a middle class, and the expansion of higher education. Over the course of the New Order period, Indonesia's urban population grew from just under 20 percent of the population to 35 percent today. Urban migration and the growth of anonymous urban neighborhoods converged to weaken the popular appeal of Indonesia's traditional religious scholars or ulama, most of whom have a long history of political moderation and are based in the countryside (see the discussion of Nahdlatul Ulama in a later section). At the same time, state programs and Islamic schools gave rise to a new class of Islamic preachers and forms of Islamic activism consistent with social and educational aspirations of the urban middle class.

Between 1965 and the early 1990s, the percentage of young adults in Indonesia with basic literacy skills rose from about 40 percent to 90 percent. ${ }^{1}$ The increase in the percentage of people completing senior high school was

\footnotetext{
${ }^{1}$ Gavin W. Jones and Chris Manning, "Labour Force and Employment during the 1980s," in Anne Booth, ed., The Oil Boom and After: Indonesian Economic Policy and Performance in the Soeharto Era (Kuala Lumpur: Oxford University Press, 1992), pp. 363-410.
} 
equally dramatic, rising from about 4 percent in 1970 to more than 30 percent today. ${ }^{2} \quad$ This educational expansion was paralleled by the development of a new, urban, Muslim middle class. Although comprising just under 15 percent of the total population (about a third of whom are Chinese and/or Christian Indonesian) the new middle class became the trend-setter for religious and cultural developments in society as a whole. It is this new class based in the professions and government service that, still today, leads the way in pioneering patterns of religious activism and leadership different from the Islamic traditionalism predominant in the countryside.

New religious organizations and heightened competition among new Islamic leaders became widespread across the Muslim world in the 1970s and 1980s. ${ }^{3}$ What was unusual about the development in Indonesia, however, was that the dominant streams in Indonesia's resurgence were moderate, not socially conservative or politically radical. Some of Indonesia's most prominent new Islamic leaders were educated in the United States; this pattern of U.S.-based education is notably rare elsewhere in the Muslim world. American educational programs directed at Muslim intellectuals were-and remain today-a powerfully moderating influence on the new class of Muslim leaders.

Radical groups did spring up on the fringes of the Muslim community, and, during the Soeharto regime's crisis of legitimacy in the 1990s, their numbers grew. However, during the 1980s and early 1990s, the most influential new Muslim leaders were people such as Nurcholish Madjid (a former leader of the Muslim Students Association, or HMI) and Abdurrahman Wahid of the traditionalist Nahdlatul Ulama (NU). Both men were supporters of religious pluralism, Western-style democracy, and heightened public participation for women. The activities of these and other moderate leaders show that the combination of higher education, a growing middle class, sustained economic expansion, and even-handed state policies all worked to give Indonesia's Islamic resurgence a moderate face. The religious resurgence in Indonesia during the 1980s and 1990s was arguably the most moderate and Westernfriendly in the whole Muslim world.

\section{The declining influence of secular nationalism}

A second, policy-relevant point that must be emphasized with regard to the resurgence, however, is that the Soeharto regime responded to the resurgence in a way that over time weakened the influence of moderates and strengthened that of hardliners. Since coming to power in early 1966, the New Order regime had strictly enforced regulations requiring that all citizens profess one

\footnotetext{
${ }^{2}$ Terence H. Hull and Gavin W. Jones, "Demographic Perspectives," in Hal Hill, ed., Indonesia's New Order: The Dynamics of Socio-Economic Transformation (Honolulu: University of Hawaii Press, 1994), pp. 123-78.

${ }^{3}$ Eickelman and Piscatori, Muslim Politics (Princeton: Princeton University Press, 1993), p. 71.
} 
of five state-sanctioned religions (Islam, Protestantism, Catholicism, Hinduism, or Buddhism). Students received two hours of religious instruction weekly from grade school up through their college years. State-sponsored programs of mosque building and religious proselytization (known from the Arabic as dakwah, or "appeal") introduced Islamic schools and organizations into villages and neighborhoods previously indifferent or even hostile to Islamic piety. By the 1980s, sociological and ethnographic reports made clear that many former bastions of secular nationalism, especially in Java (where half of Indonesia's population resides, and which previously was an important center of secular nationalism), were being swept into the Islamic revival.

The consequences of the Islamic resurgence are directly relevant to American policy considerations today. In the 1950s, secular nationalists, Western-style democrats, army technocrats, and socialists were all firmly opposed to any form of Islamic governance. Their views meant that there was a strong constituency in Indonesia committed to economic development and a more or less secular separation of religion and state. From the late 1980s on, however, many in the country's nationalist community felt obliged to make greater concessions to those demanding a heightened presence for Islam in government. Today a significant portion of the armed forces and perhaps a dominant faction in the intelligence services remain committed to a more or less secular nationalist vision of politics. In addition, a wing of the democracy movement attempted to promote a secular nationalism after Soeharto's fall in 1998. Despite these countercurrents, the legitimacy of secularist or secular nationalist ideals among the general Muslim public has declined dramatically since the resurgence.

The political consequences of secular nationalism's decline are, however, still complex. The fact that Muslims might wish to give Islam a heightened public presence does not necessarily mean that they advocate the establishment of an Islamic state or the compulsory application of Islamic law. Studies show, for example, that two-thirds of the people who voted for Megawati's Indonesian Democratic Party of Struggle in the June 1999 elections consider themselves pious Muslims. This suggests that, even while approving of the general notion that Islam should play a central role in public life, Muslim Indonesians disagree, indeed profoundly, on the precise role that Islam should play in government.

Nonetheless, a significant change in Indonesian political culture, including that of the military elite (at least its dominant faction), has taken place since the 1980s. By comparison with the period before the resurgence, secular nationalism-or, at the least, ideologies emphasizing a separation of religion and state-are in retreat. In this regard, Indonesia today differs profoundly from, say, contemporary Turkey, a country which a generation ago Indonesia otherwise resembled. Both countries once boasted the Muslim world's strongest traditions of secular nationalism. Although Turkey's secular 
nationalism remains the dominant ideology among the country's political and military elite (albeit much less so among the public at large), its counterpart in Indonesia has experienced a precipitous decline. As discussed later in this report, the decline has had an especially disorienting effect on the Indonesian armed forces, once a fierce opponent of radical Islam and supporter of secularnationalism.

In its early years, the New Order regime hoped to use its religious policies to inoculate the public from the perceived threats of Marxism and Western liberalism. The Soeharto regime also sought at first to make sure that these cultural programs did not lead to the revival of an Islamic political movement. In the early 1970s, the regime fused all of the major Muslim parties into a single party structure, whose leadership was then determined by the regime. Between 1984 and 1985, the government required religious and other "mass" organizations to incorporate the Pancasila or "five principles" of state ideology into their organizational charters; those that refused were legally dissolved. Although most mainstream organizations reluctantly assented to the government regulation, a small number of hardline Islamists refused. The activities of these radical militants were to play a role in the revival of Muslim radicalism in the 1990s and eventually led the Soeharto regime to change its policy on political Islam.

\section{The rise of the radical fringe, with an aside on the Saudi role}

A very few from among those who chose to resist the Soeharto regime's repression of political Islam in the 1970s and 1980s opted to leave the country for centers of conservative Muslim learning and militancy overseas. A significant number did so by joining the several hundred people who travel each year to Saudi Arabia for religious study, with the financial assistance of Saudi authorities. Beginning in the mid-1970s, the Saudis greatly expanded their assistance to religious groupings in Indonesia. The ultra-conservative and vehemently anti-American Indonesian Council for Islamic Predication (DDII, see below) was the single largest beneficiary of Saudi largesse. The Saudis clearly did not intend for their support to conservative Islamic organizations to encourage the growth of radical activism. However, in Indonesia's troubled circumstances, some among those who benefited from Saudi assistance eventually turned to militant extremism.

Jafar Umar Thalib and Abu Bakar Ba'asyir. It was during these same years, for example, that Jafar Umar Thalib traveled to Saudi Arabia, Pakistan, Yemen, and Afghanistan, in part with Saudi financial aid. Thalib is the paramilitary leader who in February 1998 established the vehemently anti-Christian and anti-American Forum Komunikasi Ahlus Sunnah wal Jamaah (Communication Forum for Followers of the Prophet, the patron group for the anti-Christian 
Laskar Jihad paramilitary [see below]). Like many on Indonesia's radical fringe, Thalib's early education and travel was financed by scholarships from Saudi authorities. Like many other conservative Muslims who benefited from Saudi programs, however, Thalib's views were considerably more anti-Western and militant than those of the Saudi authorities.

Although not directly assisted by the Saudis, other radicals at this time fled Indonesia and began to establish international networks that would serve them well much later. For example, Abu Bakar Ba'asyir, the leader of the Council of Islamic Fighters (Majelis Mujahidin Indonesia, established in August 2000) and a man accused by Singaporean and Malaysian officials in January 2002 of having ties to Al Qaeda, fled state prosecution in the early 1980s and established himself in nearby Malaysia. In the state of Negeri Sembilan in 1985, he established an ultra-conservative religious school (madrasa) dedicated to promulgating, among other things, the idea that Israel and the United States were global enemies of Islam. Jafar Umar Thalib and many other radicals would reconcile with the regime and return to Indonesia in the mid-1990s, as the Soeharto regime began to court conservative Muslims. Those unwilling to reconcile with the regime, such as Ba'asyir, were able to return only after Soeharto's downfall in 1998.

Despite the state's repression of political Islam in the 1970s and early 1980s, most militants opted to stay in Indonesia. Some, such as the leadership of the radical faction of the Muslim Students Organization, known by its acronym, HMI-MPO, went underground and developed a network of Islamist activists opposed to the Soeharto regime. In the post-Soeharto era, some of the former leaders of the HMI-MPO, in particular the group's founder, Eggy Sudjana, used these same networks to develop a constituency supportive of the jihad battle in Maluku and, more generally, the establishment through militant measures of an Islamic state. ${ }^{4}$ Other hardliners, such as the leadership of the Indonesian Council for Islamic Predication (DDII, founded 1967) and the Indonesian Committee for Solidarity with the Islamic World (KISDI, founded 1987), chose to concentrate their energies on Islamic predication or dakwah. The proselytization of these radical groupings included an explicitly political message. DDII and KISDI propaganda spoke repeatedly of the perfidy of the West, especially the United States, and the inevitability of Muslim conflict with Christians and Jews. Led by Muhammad Natsir (d. 1993), the leader of the

\footnotetext{
${ }^{4}$ Today's campus-based wing of the HMI-MPO, however, has evolved into a less radical organization with good deal more ideological diversity than in the late 1980s and early 1990s. Campus branches of the HMI-MPO enjoy considerable autonomy, and in the late 1990s and early 2000 some adopted a loosely democratic Islamist program; others have lent their support to hardline Islamism. The HMIMPO must also be distinguished from the mainstream HMI, also known as the HMI-DIPO. The mainstream group never went underground or into militant opposition to the Soeharto regime. Although lightly Islamist in political orientation, the mainstream HMI ideology is moderate. Both wings of the HMI joined with other campus Islamic groupings in October 2001 to protest U.S. actions in Afghanistan.
} 
largest of the Islamic parties in the 1950s, the Masyumi, the DDII benefited from extensive financial support from Saudi government authorities until the mid 1990s. Saudi assistance helped conservative groups such as the DDII to bide their time during the harsh years of New Order repression, developing an organizational and propaganda infrastructure that was to serve them well in the late Soeharto period.

\section{The Soeharto regime's outreach to Muslims}

In the mid to late 1980s, the Soeharto regime responded to the Islamic resurgence by changing tack, away from forceful repression to open cooptation. The target of the regime's outreach changed over time. At first the regime attempted to co-opt the moderate Muslim mainstream but, when its leadership proved uncooperative, the regime shifted its attentions to the radical fringe. Few developments are more important than this one for understanding the circumstances of radical Islamism in Indonesia today.

The regime's first efforts to respond to the Islamic resurgence by wooing Muslim leaders began with efforts aimed at the leadership of the largest of the country's (and the world's) Muslim organizations, the Nahdlatul Ulama or NU. Established in 1926, NU is a traditionalist and largely rural based organization that, among other things, worked with the armed forces to destroy the Communist Party during 1965-1966. Notwithstanding this latter action, NU has historically shown an accommodating attitude toward secular nationalist politicians, preferring scholarships, business deals, and government assistance to political militancy.

In 1985, Soeharto appointed NU's reform-minded leader (and President of Indonesia, October 1999-July 2001), Abdurrahman Wahid, to the People's Consultative Assembly (MPR) as a reward for Wahid's assistance in encouraging NU leaders to accept the Pancasila as the sole ideological foundation. (The agreement with NU was just one example of the "single foundation" [asas tunggal] policy the regime imposed on all social and political organizations between 1983 and 1985.) Always eccentrically independent and blunt-talking, however, Wahid eventually ran afoul of the president. In the late 1980s, Soeharto cut off funds and support to Wahid and NU and shifted his largesse to the "modernist" Muslim community, which had historically been NU's rival. During most of the 1990s, then, the Nahdlatul Ulama moved into opposition against Soeharto. Equally remarkable, the Muslim organization allied itself, not with the modernist Muslim community, but with secular nationalists, such as those in Megawati Sukarnoputri's Indonesian Democratic Party-Struggle, or PDI-P.

This regime's second effort at Muslim outreach was aimed primarily at the second largest of Indonesia's Muslim organizations, the Muhammadiyah. 
Muhammadiyah is a moderate modernist reform organization established in central Java in 1912. Although its members may participate on an individual basis in national politics, as an organization the Muhammadiyah has always avoided direct participation in politics. It sees its primary mission as religious education and social welfare. The organization operates a network of hundreds of schools (madrasa), hospitals, and universities across Indonesia. Whereas the Nahdlatul Ulama's schools are owned and operated independently by individual religious scholars, Muhammadiyah institutions are controlled by the national organization. Although orthodox on questions of prayer and doctrine (in a way that is often compared to mainstream Christian evangelicals), the Muhammadiyah has a clear and distinguished track record of political moderation.

Muhammadiyah's membership is drawn primarily from the urban middle class. However, in such provinces as West Sumatra and Central Java it also enjoys a significant rural following. With its educated urban base, the Muhammadiyah was far better positioned than Nahdlatul Ulama to benefit from the expansion of the ranks of the new Muslim middle class in the 1970s and 1980s. During those years, Muhammadiyah associates were recruited in large numbers to government bureaucracies in the capital and provinces. Quietly but insistently, these representatives worked from within the government to encourage the Soeharto regime to moderate its policies on Muslims.

The formation of the Association of Indonesian Muslim Intellectuals (ICMI) in 1991, the lifting of the prohibition on wearing veils in public schools, the establishment of an Islamic bank, the founding of an Islamic newspaper-these and other measures in the early 1990s were all seen as concessions made in an effort to court support from the Muslim modernist community. As had earlier been the case with Wahid, however, many modernists leadership proved unenthusiastic about linking themselves too closely to the authoritarian president. A few modernist leaders even lent their voices to the Muslim wing of the democracy movement. Continued criticism of the president by modernist figures such as Amien Rais (of Muhammadiyah), Nurcholish Madjid (an independent intellectual), and Dawam Rahardjo (of Muhammadiyah and ICMI) led the president's advisors to downscale their assistance to the mainstream modernist community in 1994-1995.

In its final four years, the regime shifted the focus of its cooptation efforts again. It moved away from mainstream modernists to militant hardliners previously opposed to the Soeharto regime. From 1993 to 1995, Soeharto intermediaries conducted a series of secret meetings with the leadership of the hardline wing of the modernist Islamic community, in particular with the spiritual progenitors of several of today's most extreme Islamist groupings: the Indonesian Council for Islamic Predication (DDII) and the Indonesian Committee for Solidarity with the Islamic World (KISDI). The DDII leadership 
had once figured among Soeharto's fiercest critics. Although the KISDI leadership was vehemently anti-American and anti-Jewish, it had long been more accommodating with the president. Well-placed Muslim insiders have confirmed that the president's outreach to hardliners began with KISDI, and was then extended to the DDII.

The three Soeharto aides most responsible for the outreach to Muslim hardliners were the president's son-in-law, (then) Major-General Prabowo Subianto; the commander of the armed forces, Feisal Tanjung (a man long regarded as sympathetic to Islamist interests); and Din Syamsuddin, a Muhammadiyah activist from that organization's conservative wing. Syamsuddin had always made clear that he opposed the Muhammadiyah leadership's reluctance to ally the organization with Soeharto. Syamsuddin was a close ally of one of KISDI's founders, Lukman Harun (now deceased). Syamsuddin was also General Feisal Tanjung's speech-writer in the mid-1990s, and was appointed to the directorship of the ruling Golkar party's strategy bureau in 1994. Under Syamsuddin's leadership, but at the direction of Islamist members of the military, the strategy bureau crafted the most notorious "dirty tricks" used against the political opposition in the final years of the Soeharto regime. Today Syamsuddin is a vocal proponent of conservative Islamist views, and is widely regarded as one of the most prominent opponents of American involvement in Indonesia. He is also one of the most important "mainstream" national leaders with cordial ties to Muslim paramilitaries such as the Laskar Jihad (see below).

Locked in a bitter service rivalry with the commander of the armed forces (General Wiranto), Prabowo Subianto was eventually implicated in misdeeds associated with the May 1998 riots and relieved of his armed forces command. Prabowo coordinated the writing and dissemination, for example, of a notoriously inflammatory booklet, entitled The Conspiracy to Overthrow President Soeharto, in November 1997. With Prabowo's assistance, the booklet was distributed in hardline circles in the spring of 1998. Its anti-Chinese appeals are thought to have contributed to the climate of communalist sentiment at that time. ${ }^{5}$ General Tanjung scaled back his involvements in politics after Soeharto's fall but continued to lend behind-the-scene support (reportedly including training and the provision of arms) to Islamist paramilitaries during the post-Soeharto Habibie government (1998-1999) and Wahid administration (1999-2001). Sources in the Muslim community report that in early 2000 Tanjung lent his support to radical Islamist efforts to organize Islamist paramilitaries to do battle with Christians in eastern Indonesia.

\footnotetext{
${ }^{5}$ See Robert W. Hefner, Civil Islam: Muslims and Democratization in Indonesia (Princeton: Princeton University Press, 2000), ch. 7; and International Crisis Group, Indonesia: Violence and Radical Muslims (Brussels: ICG Indonesia Briefing Paper, 10 October 2001), esp. p. 12.
} 
The third mediator in the regime's outreach to radical Islamists, Din Syamsuddin, retired from the ruling Golkar party's strategy bureau in June 1998, after Soeharto stepped down. However, interim President B.J. Habibie quickly appointed Syamsuddin to the strategic position of secretary general of the semi-governmental Council of Indonesian Islamic Scholars (Majelis Ulama Indonesia, MUI). From his position in the MUI, Syamsuddin played a leading role in coordinating behind-the-scene opposition to the reform government of Abdurrahman Wahid (October 1999 to July 2001). He also provided moral support to Islamist paramilitaries battling Christians in the Maluku islands. After the September 11, 2001, attacks on the U.S., Syamsuddin rallied Muslim sentiment behind an MUI resolution that declared that, if the U.S. attacked Afghanistan, it was the obligation of all Muslims to engage in "holy struggle" (jihad) against the U.S. These and other facts indicate that, although support among the Islamist elite in the military and government was temporarily shaken by Soeharto's fall, it continued and remains an influence today.

\section{The propagation of conspiracy theories}

The alignment of key hardline Islamist groups behind Soeharto and the Islamist wing of the armed forces, then, represented an important shift in the political culture of the late Soeharto regime. In the mid 1990s, the hardliners demonstrated their new allegiance to the Soeharto regime by lending their support to the government's policies in East Timor, and against the democracy movement, which they portrayed as Christian and pro-Western. The hardliners also played a central role in the promulgation of a new kind of propaganda never before used by the regime. The propaganda relied on conspiracy theories to discredit domestic and international opposition to the Soeharto regime. During 1994-1995, hardline conservative journals at Media Dakwah, the official organ of the DDII, began to speak for the first time of an international conspiracy, led by the United States and Israel, against Indonesia and President Soeharto.

Although its precise message varies, the virulently anti-American theme has remained central to hardline Islamist propaganda to this day. More alarming, as illustrated in the public appeals of people such as Din Syamsuddin, the message has been embraced by certain segments of the political and military elite. The message is that the United States and "international Zionism" were happy to support the Soeharto regime as long as it repressed Muslim political organizations and opened the country to international capital-but once President Soeharto began to lend his support to Muslim groupings in the late 1980s and early 1990s, the United States and Israel resolved to remove him from power and even promote the political disintegration of Indonesia. Thus, it is said, the financial crisis that broke out in late 1997 was really the work of Jewish financiers such as George Soros, and not the fault of misguided New Order policies. Similarly, it is said, U.S. misgivings about Indonesian policies 
in East Timor were motivated by Americans' sympathy for the Christian population of that island and by Americans' hatred of Islam. Conspiracy theories such as these also place blame for the violence in Maluku, Central Sulawesi, Irian, and Aceh squarely on the United States.

Although once an ally of the United States, in his last years Soeharto and his family members provided extensive support to groups promoting this fiercely anti-American, anti-Christian, and anti-Semitic message. In a rare interview with Japanese journalists almost a year after his resignation, Soeharto again blamed Jews for his ouster. As will be discussed below, Islamist elements in the political elite and armed forces give voice to similarly anti-American views today. 


\section{Radical Muslims, the armed forces, and Muslim political parties}

The economic crisis that caused the Indonesian economy to contract some 15 percent during 1998 gave rise to greatly elevated rates of unemployment and underemployment, especially among urban male youth. These economic circumstances converged with the decline of secular nationalism and the seeming incapacity of the central government to control crime and ethnic violence, to create deep dissatisfaction among large segments of the Muslim public. This situation created a fertile breeding ground for recruitment to radical Islamist paramilitaries and gangs.

\section{The elections of June 1999 illustrated Muslim moderation}

It is important to emphasize, however, that the elections of June 1999 indicated that most Indonesian Muslims remained moderate in political orientation and uninterested in radical proposals to establish an Islamic state. Only about 16 percent of the 1999 vote went to parties advocating an Islamization of the government-whereas in the last genuinely free elections, which took place in 1955, more than 40 percent of the vote went to parties advocating the establishment of an Islamic state (in some, largely unspecified, way). As noted above, however, most other social indicators suggest that the country's Muslim population is far more conscientious about the conduct of religious duties than it was a generation ago. This suggests that it is not the Islamic resurgence per se that presents a destabilizing challenge in today's Indonesia, but the ability of a small, conservative segment of the Muslim community to exercise a political influence vastly out of proportion to its representation in society. A central challenge to understanding Islamist politics in Indonesia today is to understand how this came to be so.

In the post-Soeharto period, radical Muslims worked hard to overcome their limited support in society by attempting to establish close ties to antiWestern and anti-reform factions in the armed forces, most notably in the army. Typically, these alliances have been forged in secret, in part because broad sections of the army, and probably the great majority of officers in the other services, disapprove of collaboration with Islamist paramilitiaries.

In the months following Soeharto's resignation, however, hardline Muslims (linked to KISDI) continued to rally in support of the army and against those calling for investigations of the May violence and the rapes of Chinese women. The conservatives claimed that the NGOs and others investigating the violence were Christians and secularists intent on discrediting Muslims, the military, and Indonesia. Conservatives in groups such as KISDI and the DDII also attacked 
the democracy movement, claiming that it was anti-Islamic, pro-Western, and secularist.

Although these pro-military appeals resonated little with the Muslim community as a whole, they were the basis on which some army officers opted to continue the policy of the late Soeharto era; indeed, some commanders actually expanded their collaboration with Islamist radicals. For example, one of today's largest Islamist paramilitaries-the Islamic Defenders Front, or FPI (Front Pembela Islam) —was established on August 17, 1998, with the direct assistance of high-ranking members of the military, including the thencommander of the armed forces, General Wiranto. Since its founding, the FPI has proved itself to be one of the most violent and anti-American of the paramilitaries in Indonesia. It was the FPI that spearheaded Islamist demonstrations against the United States after September 11, 2001. In October 2001, the commander of the FPI called for Indonesia to sever ties with the U.S. He also threatened to shut down the American embassy and conduct "sweepings" of hotels in search of Americans and British citizens. In the end, no Americans were detained by the paramilitaries. But Islamist paramilitaries did conduct sweeping in the city of Surakarta in Central Java. In several instances, American visitors (whom I have interviewed) were saved from assault only by kind hotel owners, who hid them.

Led by conservative Arab Indonesians with family ties to Yemen, the FPI leadership had earlier collaborated with the Indonesian Council for Islamic Predication (DDII) and received funds from Saudi sponsors. ${ }^{6}$ Viewed from the perspective of hardline Islamists and a faction in the army, the FPI was the institutional successor to the less formalized Islamist paramilitaries established with the support of General Feisal Tanjung, Prabowo Subianto, and other socalled "green" officers during the final months of the Soeharto regime. Some among the FPI militants were idealistic if fanatical Islamists opposed to Western culture and convinced that there was a Western and Jewish conspiracy against Muslim Indonesia. Others, particularly in the rank and file, were simply unemployed urban youth attracted to the paramilitaries by their tough image and the promise of payment for each action they joined.

\footnotetext{
${ }^{6}$ The leaders of both the FPI and the Laskar Jihad include a disproportionately large number of ArabIndonesians. Some observers, including some moderate Indonesian Muslims, believe that this ethnic variable has reinforced the weak identification of these Arab-Indonesian leaders with the moderate Islam widespread among Indonesian Muslims. It is true that pious Arab Indonesians tend to maintain close ties with relatives and Muslim organizations in the Middle East, including, especially, Yemen. However, it should also be emphasized that Arab-Indonesians are also disproportionately represented in the ranks of the country's democracy and human rights organizations. They also played a proud role in the Indonesian struggle for national independence. The most significant indicator of Islamist radicalism among Indonesian Muslim leaders, then, may have less to do with Arab ethnicity than the strength of ties to radical organizations in the Middle East.
} 
The varied ideological orientations of the paramilitaries. The attraction of some of the paramilitaries includes the prospect of regular employment and irregular income. Economic motives of this sort are particularly apparent in the Islamic Defenders Front (FPI), whose activities blur the divide between religious vigilantism and criminality, including racketeering and extortion. Indonesia's four-year economic crisis has provided a fertile recruiting ground for masses of unemployed and underemployed Muslim youth. Indeed, recruits to Islamist groupings such as the FPI, with their unusual mix of religion and criminal syndicalism, include members of a distinctively Indonesian form of criminal syndicate known as preman.

Economic incentives of this sort are less important among the rank and file in groups like the Laskar Jihad and the Laskar Mujahidin (of the MMI). The membership of these paramilitaries tends to be more affluent, better educated, and more ideological than that of the the FPI. In fact, recruits to organizations like the MMI's Laskar Mujahidin often make considerable economic sacrifices to participate in activities like the jihad in Maluku.

The role of politico-criminal syndicates (preman). However small their representation in Indonesian society, preman gangs play an important role in Indonesian politics in general and Muslim politics in particular. The Soeharto regime and the military regularly relied on preman gang members for undercover and extralegal actions over the course of the New Order. The pattern began as early as 1965-1966, when army officials recruited members of one gang, the "Pancasila Youth" (Pemuda Pancasila), to cleanse the city of Medan of Communist sympathizers. A similar policy was used to recruit marginal and unemployed toughs into the ranks of anti-independence paramilitaries in East Timor and elsewhere during the 1990s.

In addition to violence and criminal activities (extortion, prostitution, etc.), the largest preman gangs adopt an ideological garb in their public communications, aligning themselves with the slogans and campaigns of their sponsors. Interestingly, in the final months of the Soeharto era and the postSoeharto period, the ideological complexion of the most powerful gangs changed. Whereas the Pemuda Pancasila and other gangs who had worked with the regime in the 1970 s were broadly nationalist in orientation and included numerous Christian gang members, most of the gangs working with the regime in the late 1990s affected hardline Islamist styles. New groups such as the FPI made a special effort to recruit conservative religious scholars to serve as their spokespersons.

Of all the paramilitaries currently operating in Indonesia, the Islamic Defenders Front, or FPI, is the organization most directly linked to a proIslamic faction in the army. At the time of its founding in August 1998, the FPI benefited from support provided by the commander of the armed forces, 
General Wiranto. This association is ironic: During late 1997 and early 1998, when he was locked in a service rivalry with Soeharto's son-in-law, Lieutenant General Prabowo Subianto (one of the most notorious "green" or Islamist generals), General Wiranto had earned the admiration of many Indonesian and Western observers for his opposition to Islamist extremism. However, just weeks after Soeharto's resignation, General Wiranto called in several of the most prominent advisors to hardline Islamists and informed them, as one such person told me directly, "Now you're working for me."

Working with Nugroho Jayussman (commander of the Jakarta police force) and other generals, General Wiranto played a dominant role in sponsoring the formation of the Islamic Defenders Front (FPI). Wiranto and Jayussman first relied heavily on the FPI and other Islamist paramilitaries in November 1998. At that time democracy activists, backed up by nationalist members of the political elite (including many armed forces retirees), threatened to stage large demonstrations against interim President Habibie and the special session of the People's Consultative Assembly (MPR) called by him. Some Muslim sources in the capital report that the former President Soeharto provided Wiranto with funds for the FPI and the 100,000-plus Islamist militants known as Pam Swakarsa who were brought in by the police and military to "protect" the special session of the MPR. However, this report of Soeharto funding has not been independently confirmed.

Many military sponsors of Islamist groups are not motivated by religious concerns. Whatever the degree of Soeharto family involvement in the Pam Swakarsa, the evidence indicates that Wiranto and other members of the military actually expanded their sponsorship of hardline paramilitaries in the post-Soeharto period. The fact that Wiranto-a man long regarded as broadly "nationalist" in orientation, and with no history of prior anti-Christian, antiChinese, or anti-Western behavior-became so heavily involved with Islamist paramilitaries suggests that policy analysts should take care not to conclude that ideology or religious conviction is the primary motive for these alliances. Although there certainly are army commanders with fiercely anti-Christian and anti-American views, such as retired major Rustam Kastor, the main military defender of the jihad fighters in Maluku (see below), most commanders opted to work with the paramilitaries simply because they were the only large civilian force willing and able to provide vitally needed services.

State control of the Islamists is limited by factionalism and the state's weakened authority. However much groups such as the FPI have benefited from funds and protection offered by army commanders, however, policy analysts should take care not to view Islamist paramilitaries as mere puppets of military or political figures. The precise relationship between the two groups appears to be more a matter of opportunistic convergence rather than ideological agreement or, least of all, systematic control. 
In evaluating the strength of the radical groups and the nature of their relationship with their military patrons, it is important to keep in mind two key characteristics of the post-Soeharto era: first, "Jakarta" or the central state no longer exercises the exhaustive control it once did over politics and society in the provinces; second, neither the civilian nor military elite still has the ideological cohesion it did at the height of the New Order. The final years of the New Order were marked by bitter intra-military and intra-elite battles between supporters of secular nationalist politics and those advocating closer cooperation with radical Islamists. Rather than declining in the post-Soeharto period, this fractionalization has intensified in a manner that has provided considerable tactical opportunities for Islamist paramilitaries.

A key feature of the post-Soeharto era is that, aside from Soeharto and a few of his closest allies, most of the old regime remained in place after the president's departure. The Dutch social historian Kees van Dijk observed that, "The 'Reformation Order' which had come into being was not much more than the New Order minus the Soeharto family" (van Dijk, A Country in Despair, 2001, p. 298). Although, in other countries' political transitions, continuity of this sort might lead some observers to speculate that old regime stalwarts would unite against the forces of reform, what happened in fact was not nearly so simple. Old regime holdovers did obstruct portions of the reform program, but they were far from united in their efforts.

At both the national and local level, political elites of all kinds-not just the military-responded to the ideological and administrative vacuum created by Soeharto's departure by reaching out to groupings in society in an effort to mobilize popular support against rivals. In some parts of the country, such as Yogyakarta and East Kalimantan, the local administration managed to keep this patronage-cum-ideological competition within civil bounds. In Maluku, Central Kalimantan, Poso, and a few other regions, however, contestants resorted to mobilizing support by appealing to ethnic and religious divisions. In several instances, this populist sectarianism was made worse by rival elites' reliance on preman gangsters, who have a history of using brutal violence to get their way. In places such as Maluku or the Poso region of Central Sulawesi, where rivalries among local bosses involved a flammable mixture of elite factionalism, extra-legal gangsterism, and ethno-religious tensions, the result has been explosive violence. In Central Sulawesi and Maluku, Christian paramilitaries have participated in attacks on civilian populations as much as have Muslims. 


\section{A comparison of the FPI, Laskar Jihad, and Majelis Mujahidin}

Another reason it is important not to see the Islamist paramilitaries as mere puppets of all-powerful military bosses concerns the varied organization and ideological disposition of the paramilitaries themselves. There are now hundreds of Islamist paramilitaries operating across Indonesia. Muslim sources in Surakarta, Central Java, have indicated that there are literally dozens of groups in that city alone (a bastion of hardline Islamism). Some groups are loosely linked to broader, national organizations such as, most notably, the Islamic Defenders Front (FPI), the largest of the Islamist paramilitaries. But others are undisciplined, freelance groups independent of any national organization.

Equally important is that the precise measure of collaboration with civilian and, especially, military sponsors varies from group to group. Some groups work closely with military sponsors; others reject such collaboration. The dynamics of this variation can be seen through a brief comparison of three of the most important paramilitaries: the Islamic Defenders Front (FPI), the Yogyakarta-based Laskar Jihad (jihad paramiliary), and the much smaller but still national, Laskar Mujahidin of the Council of Islamic Fighters or Majelis Mujahidin Indonesia.

\section{The Islamic Defenders Front (FPI)}

Of these three groups, the FPI is the only one whose leadership is based in the national capital. As noted above, the FPI also has the longest and clearest history of collaboration with military sponsors. However, it is instructive to recall that even this organization clashed with police officials several times during 2000 and 2001. In one well-publicized incident, FPI activists on a bus were actually fired on by uniformed police officers aiming to prevent FPI activists from launching a raid on centers of "vice" to which the Islamists objected. In the aftermath of such clashes, the FPI leadership threatened violence against any police and army officials who dared to take such measures in the future. This defiance illustrates both the FPI's relative autonomy from military sponsors and, more important, the leadership's awareness that there are significant factions in the army, the police, and, perhaps most important, the intelligence community who would be happy to see the FPI suppressed.

\section{The Laskar Jihad}

If the FPI has on occasion demonstrated a measure of independence vis à vis the police and army, the same tendency is all the more pronounced in the case of the Yogyakarta-based "jihad paramilitary" or Laskar Jihad. This organization 
is, by far, the largest and best organized of the Islamist paramilitaries doing battle against Christians in Maluku and the Poso region of Central Sulawesi. In mid-2001 the organization claimed to have 2,000 fighters the field, and another 6,000-8,000 who had already done three-month tours of duty in Maluku.

The Laskar Jihad grew out of a larger, conservative religious movement known as the Forum Komunikasi Ahlus Sunnah wal Jamaah, founded in Yogyakarta, Central Java in 1994. The FKAWJ, as it is known, is led by a young (b. December 1961) Arab Indonesian, Jafar Umar Thalib. However much Jafar may be willing to collaborate with pro-Islamist commanders in the armed forces, he himself is driven by deep ideological and religious convictions. He lives simply; he enforces a strict discipline on his troops; and, quite unlike the undisciplined FPI, his fighters do not extort civilians. On the contrary, they devote as much of their time to religious and ideological education as to battle.

A key feature of this movement is its identification as "Salafy," a reference to a long-established movement in Islam that aims to model profession of the faith on the example of the first generation of followers of the Prophet. However, in the form promoted by Thalib, the movement is best understood as neofundamentalist or "neo-Salafy," because it emphasizes political concerns not associated with earlier variants of Salafism. The most important of these is the firm belief that there is a worldwide conspiracy led by the United States and Israel against Islam in general and Indonesia in particular. In this and many other regards, the FKAWJ ideology bears a striking resemblance to the Afghanistan Taliban, a group with whom Jafar has publicly aligned himself. However, as I note in a later section, this ideological affinity does not extend to direct cooperation with $\mathrm{Al}$ Qaeda, although contacts have occurred.

Jafar Umar Thalib began his career studying in a conservative modernist religious school in Bangil, East Java, in 1981. Unhappy with the apolitical nature of his instruction, he soon traveled to Jakarta to study at the Saudisponsored Institute for Islamic and Arabic Studies. In the capital, Thalib became active in student groups opposed to the secular nationalist policies of the Soeharto regime. Awarded a scholarship by the conservative Indonesian Council for Islamic Predication (DDII), Thalib traveled in 1986 to Saudi Arabia for further religious study. Again impatient with the apolitical nature of his lessons, he left for Afghanistan in 1987 under the auspices of the Saudisponsored Muslim World League. In Afghanistan, he met briefly with Osama bin Laden, but opted to join with a faction of the mujahidin with ties to the Saudis rather than Osama. In 1989, Thalib returned to Indonesia, accepting a teaching post at a conservative Islamic school in Salatiga, Central Java. In 1990, he returned to Yemen, to engage in further study with an ultraconservative religious scholar known for his close ties to salafy scholars in Saudi Arabia. Thalib returned again to Indonesia in 1993. Eager to make a name for 
himself, in 1994 he founded a religious school 12 miles north of the city of Yogyakarta in the subdistrict of Kaliurang.

A major difference between the FKAWJ and more criminally inclined paramilitaries such as the FPI is that the former has always focused his proselytizing efforts, not on the Muslim community as a whole, but on middleclass university students in the exact sciences and professions. Students with these backgrounds, Thalib explained to me in August 2001, appreciate the "precision" of Islamic law. They also have provided the FKAWJ with propaganda capabilities unparalleled among the Islamist groupings (or, for that matter, in the Muslim community as a whole). In cooperation with its militia, the FKAWJ operates a popular website which carries news on national politics, the battle against Christians in Maluku and Poso, and a host of international events. Interestingly, in early 2001 the website also featured links to Chechen Islamist fighters, and featured gruesome videos of Chechens mutilating Russian soldiers. These web links to international Islamists disappeared from the FKAWJ website sometime during late 2001-perhaps in response to American allegations that the FKAWJ might be linked to Al Qaeda.

In addition to its internet sites, the FKAWJ and Laskar Jihad publish daily bulletins on the battle in Maluku. Downloaded from the internet and printed independently in cities across Indonesia (on the model of, in this regard, USA Today), these bulletins are distributed for free by Laskar Jihad supporters across Indonesia. The FKAWJ also publishes a monthly magazine, salafy, and periodic topical publications. Thalib's forces also operate clandestine Islamist radio stations in Maluku and Poso. Marked by their ferociously anti-Christian and anti-American propaganda, these stations have helped to inflame Muslim anger over alleged Christian provocations. In short, despite their relatively small membership, the FKAWJ and Laskar Jihad operate what are arguably the most sophisticated Muslim media facilities in Indonesia.

Jafar Umar Thalib's propaganda skills also extend to his appearances at large public rallies. Thalib's orations are notable for their ideological sophistication and extensive religious references, in a manner that contrasts with the low brow populism of the FPI. In sermons marked by fiery cadences and emotional exhortations, Thalib hammers away at his themes of the failures of secular nationalism, the perfidy of infidels (especially Christians), and, most important, the need for Muslims to wage jihad. Jihad is required, Thalib emphasizes, so as to cleanse society of un-Islamic influences. It is also needed to ensure that unbelievers understand that their proper status in society must be that of protected minorities (dhimmi). A concept from classical Islamic tradition, dhimmihood stipulates that non-Muslims not be allowed to exercise authority over Muslims. Unlike most of Muslim leaders, Thalib makes clear that he believes that the equal citizenship sanctioned by the Indonesian constitution is utterly antithetical to Islam. 
Jafar Umar Thalib's organization has long been reported to have ties with hardline politicians and military officials. Reports in the Yogyakarta Muslim community during 1999 asserted that Probosutedjo, ex-President Soeharto's half brother, had provided financial aid to the FKAWJ during its first years, but these allegations have never been independently confirmed. Other Muslim reports offer a related claim, suggesting that Thalib, whose birthplace is Malang, in East Java, was recruited by the Soeharto regime to set up a religious school in the Yogyakarta region so as to counteract pro-democracy activism in this long-influential intellectual city. These reports, too, cannot be confirmed.

Whatever the precise degree of collaboration with elite sponsors in the FKAWJ's early years, the evidence since 2000 strongly indicates a high level of collaboration. A former mid-level field commander of the Laskar Jihad, interviewed in August 2001 in Yogyakarta provided a sense of just how the early phases of this collaboration were arranged. He explained that Thalib was approached in January 2000 by military retirees with the message that they approved of his plans to escalate the armed campaign against Christians in Maluku. These agents made clear that they were willing to support Thalib's Maluku campaign, not to punish Christians, but to undermine the reform government of Abdurrahman Wahid. Jakartan Muslim activists whom I interviewed in August 2001 provided additional details on these elite linkages. They noted, for example, that a leading Arab businessman and ex-minister with close ties to former President Soeharto coordinated a vast flow of funds and arms to the jihad forces after February 2000.

In a similar vein, the International Crisis Group's report on the violence in Maluku, "Indonesia: The Search for Peace in Maluku" (issued on February 8, 2002), notes that, after the formal founding of the Laskar Jihad in February 2000, out-of-uniform members of the Indonesian National Military (TNI) helped to train Jihad fighters at a training camp outside of Bogor, West Java. Support of this sort was also evident in Laskar Jihad's ability to brandish weapons in the capital in front of the presidential palace on April 7, 2000, without so much as a single police official taking action. Similar military support was apparent in the militia's ability to travel across Java from Bogor to Surabaya without once encountering a challenge to its movements. Despite the fact that the president, minister of defense, and governor of Maluku province had all appealed to security officials to stop the militia from traveling to Maluku, the militants made their way unimpeded across Java. Eyewitnesses reports indicate they were accompanied at times by military escorts. In Surabaya, the fighters boarded state-owned ferries for Maluku. Upon their arrival in Maluku, the fighters were escorted into the city and provided with weapons. The weapons had been shipped separately from Surabaya, in case the fighters were stopped by military authorities opposed to the Laskar Jihad. The ICG report cites similar evidence indicating extensive collaboration 
between the Laskar Jihad and certain army officials. Indeed, the ICG reports, as I have reported, that army operatives have shared arms and military personnel with the Laskar Jihad in numerous incidents. ${ }^{7}$

Other military officials clearly oppose the Islamist paramilitaries. It is important to emphasize, however, that some members of the army and, especially, the police in Maluku are also reported to have provided assistance to "Christian" fighters battling Muslims. Like this report, the ICG report emphasizes that such collaboration, whether with Muslim or "Christian" militias, is in direct defiance of other officials in the police and army who wish to contain the Maluku conflict.

Just as the FPI has clashed with the police, the three-year history of the Laskar Jihad has been marked by repeated skirmishes with security officials. Since the Laskar Jihad arrived in Maluku in April 2000, the Muslim paramilitary has had several clashes with, especially, the mobile police unit known as Brimob. Police units in the Ambon region of Maluku have recruited heavily over the years from the local Christian community. Not surprisingly then, some police have occasionally sided with their Christian brothers in battles with Muslim fighters.

In June 2000, responding to what it claimed was police bias against the Muslim side, the Laskar Jihad mounted a fierce assault on a Brimob armory in the Tantui region of Ambon, Maluku, seizing ammunition and 700 automatic weapons. (Reports from the Muslim side claim, however, that the police removed the automatic weapons before the assault and gave them to Christian militias!). An even more dramatic illustration of military opposition to the Laskar Jihad occurred after the arrival in August 2000 of a special "Joint Battalion." The Joint Battalion consisted of 450 soldiers drawn from the army, the marines (who are a unit in the navy), and the air force. Its purpose was to create a military force capable of restoring law and order without siding with either of the combatants in the Maluku violence.

Shortly after arriving in Maluku, the Joint Battalion clashed with locally based Muslim fighters in August 2000. The unit did battle with Muslim fighters again in January 2001. In a later incident, on June 14, 2001, the Joint Battalion swept through a district in Ambon controlled by the Laskar Jihad, laying siege to a Jihad polyclinic. It ended by arresting many fighters and killing 23 Muslims. The Laskar Jihad accused the Joint Battalion of being controlled by Christians. Jafar Umar Thalib immediately issued a religious declaration (or fatwa), which was posted on the Laskar Jihad website, in which he called for Muslims to execute the military commander for the Maluku region (who happened to be a Hindu). Shortly after this time, the commander was transferred and the Joint

\footnotetext{
${ }^{7}$ On July 14, 2000, even the minister of defense, Juwono Sudarsono, complained publicly that army officials in Ambon had done nothing to prevent shipment of arms from Java reaching the Jihad militants. See Jakarta Post, July 15, 2000.
} 
Battalion was replaced by army special forces (Kopassus) long thought to have cordial ties with Muslims.

These and other incidents indicate that, however much some bureaucrats and army officials have aided the Laskar Jihad, other factions in the civil administration and military disapprove of the relationship, and have been willing on occasion to take firm measures against the paramilitary.

\section{The Laskar Mujahidin}

The third and smallest of the Islamist paramilitaries to be discussed here, the Laskar Mujahidin, has a history of notably cool relations, at best, with the armed forces and, more generally, the Indonesian state. The Laskar Mujahidin is the armed wing of the Council of Islamic Fighters, or Majelis Mujahidin Indonesia (MMI). The MMI was established in Yogyakarta in August 2000, at a national conference attended by more than 1,000 delegates. The purpose of the conference was to mobilize a national campaign in support of the implementation of Islamic law (shariah) across Indonesia. The Council includes among its senior leadership many prominent intellectuals and politicians. Some are conservative only on religious matters. For example, the Cornell University trained historian Deliar Noer, a conservative figure but not a violent extremist, sits on the board of advisors of the MMI.

The dominant group in the MMI leadership, however, are individuals associated with the much reviled (in mainstream political circles) Darul Islam (DI). The DI is a movement that declared an Islamic state and then did battle with the armed forces of the young republic from 1948 to 1962. In military circles, the Darul Islam has long been regarded as an Islamist movement as pernicious as the Indonesian Communist Party, because it fought Indonesia's armed forces while the latter were still battling the Dutch for independence. For these reasons, even Islamist sympathizers in the military appear reluctant to collaborate with the MMI's paramilitary, for fear of being regarded as supporters of the DI.

The Laskar Mujahidin and Al Qaeda. Other figures of more extremist orientation in the MMI include Riduan Isamuddin, alias Hambali. In February 2002, Hambali was identified by Singapore authorities as one of the masterminds of the Jemaah Islamiyah, a shadowy network that has perhaps a few hundred supporters across Malaysia, the southern Philippines, and Indonesia. It is unclear whether the JI is a loosely organized affinity group, or an actual organization with a central leadership. Singapore authorities have alleged the latter, and claim that the organization's long-term goal is to establish an Islamic state across this same region. Singapore authorities also claimed that Hambali was the mastermind of the plot to blow up Western embassies and naval vessels in Singapore in the aftermath of September 11. 
Malaysian authorities have also identified Hambali as a person who, in January 2000, arranged accommodations in Malaysia for Khalid Almihdhar and Nawaf Alhazmi, two of the hijackers of the American Airlines Flight 77 that crashed into the Pentagon. Philippine authorities have also alleged-albeit with less convincing evidence-that Hambali was involved in the 1995 plot to bring down 12 U.S. passenger jets.

Although the evidence to confirm these accusations remains incomplete, the overall portrait it provides is suggestive. The spiritual leader of the Council of Islamic Fighters is Abu Bakar Ba'asyir (age 64), a man referred to as the MMI's emir. Ba'asyir and Hambali lived in Malaysia in the 1990s, where together they formed the Jemaah Islamiyah. In January 2002 Malaysian and Philippines intelligence identified Ba'asyir as the spiritual leader of the shadowy Jemaah Islamiyah. Ba'asyir served prison time in the late 1970s for his opposition to Soeharto politics and the Pancasila, and fled to Malaysia in the early 1980s. When, in the mid-1990s, hardline Islamists in groups such as KISDI and the Dewan Dakwah Islamiyah Indonesia reconciled with President Soeharto and joined him in attacking the democracy movement, Ba'asyir and his associates remained unreconstructed critics of Soeharto and the armed forces. Together with the prominence of many former activists from the Darul Islam in its ranks, this legacy explains in large part why Ba'asyir and the Majelis Mujahidin Indonesia have not enjoyed the cordial reception that certain officers in the armed forces have shown other Islamist paramilitaries.

In Maluku province, the Laskar Mujahidin operates in a far more clandestine manner than the Laskar Jihad, no doubt in part because it does not enjoy the support of military sponsors. Laskar Jihad officials interviewed in Yogyakarta in July-August 2001 went out of their way to distance themselves from the Laskar Mujahidin. They noted, for example, that they did not approve of the fact that there were Darul Islam supporters in the organization (again, a fact that darkens the organization in the eyes of the military). In July 2001, MMI leaders claimed to have about 200 fighters in the field at the time, a much smaller force than the Laskar Jihad.

Although their media facilities are not as sophisticated as those of the Laskar Jihad, the MMI and Laskar Mujahidin have direct ties to a well-run Yogyakarta publisher of extremist Islamist tracts, the Wihdah Press. The Wihdah Press was founded, and is controlled today, by Irfan S. Awwas (born Irfan Suryahardi in 1960). An intelligent and fiercely independent militant who served nine years in prison for his opposition to Soeharto policies, Awwas was the primary convener of the August 2000 congress that led to the establishment of the Majelis Mujahidin Indonesia. His press is a major publisher of conservative Islamist books, including many of a strongly anti-Western and anti-Semitic nature. Wihdah Press has also been the publisher of one of the most inflammatory works on the violence in Maluku, Rustam Kastor's Konspirasi 
Politik RMS dan Kristen Menghancurkan Umat Islam di Ambon-Maluku (The Political Conspiracy of the South Maluku Republic and Christians to Destroy the Muslim Community in Ambon Maluku). The press has also published two sequels by Kastor.

Born in 1939, Brigadier General Rustam is a retired army commander of Ambonese background who has been the most vocal military spokesperson for the jihad forces. His Muslim supporters claim that he has had regular contacts with General Wiranto, although these contacts, if real, have never been publicly confirmed. Kastor's books and public statements argue, not merely that there is a Christian conspiracy to destroy Muslims in Maluku, but that Jews and the United States are also behind the plot. Equally revealing, while laying primary blame for violence in Maluku on alleged Christian separatists, Kastor also accuses the democracy movement of having prepared the ground for the violence by weakening the army's ability to take firm action in the province. Kastor's association with Wihdah press and, indirectly, the MMI, shows that there are at least a few individuals in the armed forces willing to cooperate with this extremist group.

The importance of U.S. policy makers' awareness of intra-military factionalism on Islam. Taken together, the relationship of these three groups to the armed forces indicates that, in attempting to devise policies that might curtail violent extremism, care must be taken to recognize (a) the factionalism that exists in armed forces, and (b) the varied nature of the relationship that different paramilitaries have with military and civilian leaders. Of the three groups, the FPI could probably be most easily subject to outside pressure, were its military sponsors to conclude it was in their interest to rein the organization in. The Majelis Mujahidin Indonesia will probably be the most difficult paramilitary to contain, since its inner circle is driven by a deeply felt ideological understanding of Muslim politics, history, and antipaty toward the West. The Laskar Jihad, finally, may well undergo the most dramatic shift in its political tack in the months to come. Jafar Umar Thalib gives signs of wanting to transform his organization into a national political party, or align it with an existing party. Behind the scenes, he has worked assiduously to develop ties with prominent Muslim politicians, including Vice President Hamzah Haz of the United Development Party (PPP). His arrest in May 2002 on charges of incitement to violence (related to a speech he gave opposing the April 2002 peace agreement in Maluku) indicates that his opponents in the armed forces and political elite are showing a new boldness. But Thalib's political career may not yet be over. 


\section{Muslim parties and social organizations}

This overview of the Islamist paramilitaries illustrates that Islamic social organizations and political parties have played a far less significant role in sponsoring or supporting paramilitary extremists than have factions in the Indonesian armed forces and political elite, national and local. The two largest Islamic social organizations, the Muhammadiyah and Nahdlatul Ulama, have consistently condemned the activities of the paramilitaries-although a few individuals in these organizations, acting on their own, have lent their support to radical actions. The NU-linked political party known as the PKB (Party of National Ascent) has been especially vocal among the parties condemning Islamist radicalism and the paramilitaries.

From hesitation to moral backing for actions previously seen as extremist. The other Muslim parties, however, especially the PPP (United Development Party), PBB (Party of Moon and Stars), PAN (National Mandate Party), and PK (Justice Party), have been more ambiguous in their attitude toward the Islamic paramilitaries. As initial hesitancies to support Muslim fighters have waned, and as a growing number of ordinary Muslims have begun to believe there is an international conspiracy against Islam and Indonesia, some in these parties began to lend their support to the jihad fighters. Factions in the PPP and PBB have gone further, accusing Christians of treason and openly supporting calls for violent action against Christians in Maluku. A few in all of these parties, finally, have even joined the jihad fighters.

A pro-Islamist faction in the former ruling party, Golkar, has also publicly backed the paramilitaries and the Maluku jihad. However, Golkar appears to be deeply divided on the question of the paramilitaries and Islamic issues in general. $^{8}$

When Islamist paramilitaries first became prominent on the national scene in the second half of 1998, few Indonesian or foreign observers anticipated how successful they would be at changing the basic terms of debate in the Muslim community. In the months following Soeharto's resignation, much of the Muslim population indicated that it was eager for a new and more democratic political format. Although in the final months of the Soeharto regime the country had been rocked by anti-Chinese riots-some of highly suspicious origins-Muslim-Christian violence had been relatively rare. This changed very quickly in the months following Soeharto's resignation. Violence that pitted non-Muslims, especially Christians, against Muslims broke out in several

\footnotetext{
${ }^{8}$ Of the parties listed, PAN, the National Mandate Party, was established in 1998 as a multireligious party under the leadership of Amien Rais of Muhammadiyah. However, after PAN's performance in the June 1999 elections failed to achieve even half of the 15 percent of the vote its leadership had anticipated, Rais pushed the party solidly back into the Muslim political camp. Most Christians and pluralist Muslims deserted the party during 2000 and 2001.
} 
portions of the archipelago, including Central Kalimantan, West Kalimantan, and Central Sulawesi. The violence between Christians and Muslims in the Ambon region of Maluku had the most unsettling effect on the Muslim community.

Small incidents of violence had already broken out in that troubled province during the mid-1990s. The province of Maluku (since 1999 divided into two provinces, North and South Maluku) is one of only six of 26 provinces in Indonesia in which Muslims have not been historically the majority population. In the 1980s and 1990s, however, Muslim immigration, mainly from the nearby island of Sulawesi, changed the province's demographic profile. Today, Muslims outnumber Christians by a small margin in the province of South Maluku, and greatly outnumber them in the north. To make matters worse for local Christians, many of the hardworking Muslim immigrants proved more skilled at small- and medium-scale enterprises than the indigenous Christian population. In addition, finally, the Soeharto regime's courtship of Islam in the 1990s was accompanied in Maluku by the appointment of Muslims to key provincial posts previously monopolized by Christians. All of these developments made the indigenous Christians more resentful of the Muslim immigrants.

There were several small clashes between the two groups before 1999; however, large-scale violence did not break out until January 1999. From that point on, it spread to other islands in the Maluku archipelago. By late 1999, government statistics indicated that some 5,000 people had been killed, and more than 700,000 of the original province's 2.1 million people displaced. This refugee population has proved to be a rich recruiting ground for radicals from both the Muslim and Christian communities. Refugees from both communities have also carried their resentments to other provinces in Indonesia, especially South Sulawesi (to which many Muslim refugees have fled) and North Sulawesi (a majority Christian territory). The refugee population may well remain a fertile ground for religious extremism, Christian and Muslim, for some time to come.

Like their Muslim counterparts, Christian militias in Maluku are nominally led by prominent religious figures. However, the militias' field commanders are recruited overwhelmingly from the ranks of local toughs and preman (see above). Christian militias enjoyed a small advantage over their Muslim rivals in the first phase of the Maluku conflict during 1999. But as the violence dragged on and the central government (first under President Habibie, and, after October 1999, under President Wahid) seemed unable to get it under control, however, hardline Muslims in Jakarta and Java appealed to Muslims to join in a campaign of jihad against Christian fighters in the troubled province. A rally organized by hardline Muslims and demanding that the government take action took place in the nation's capital as early as January 7, 2000. Among 
those in attendance were Amien Rais of Muhammadiyah (also the leader of the National Mandate Party, or PAN), Hamzah Haz of the Islamic United Development Party (PPP) and currently Indonesia's vice president, and hardline Islamists from KISDI and the DDII. The rally marked the effective end of the multiparty Muslim alliance that had united behind the candidacy of Abdurrahman Wahid for president in October 1999. The event also signaled a fundamental realignment of the more conservative Muslim parties against the more inclusively pluralistic polities of the democracy movement.

The rally and subsequent jihad campaign were indicative of the way in which the crisis of governance has greatly undermined the influence of moderate Muslims while allowing radical Islamists and their paramilitaries to exercise an influence out of proportion to their representation in society. The moderate Muslims in mainstream political organizations were unprepared for the scale and rapidity of the radicals' mobilization, and, like the non-Islamist military, seemed to be caught off guard (see below).

Wahid's shortcomings played into radical hands. In addition to MuslimChristian violence, another factor that undermined the influence of moderate Muslims was the failure of President Abdurrahman Wahid to consolidate the broad coalition that had brought him to the presidency in October 1999. The "middle axis" (poros tengah) in that coalition was a diverse assortment of Islamic parties who opposed Megawati Sukarnoputri, the leader of the Indonesian Democratic Party-Struggle, becoming president, even though her party had won the largest share of the vote in the June 1999 elections.

By any political measure, holding the middle axis together would have been a daunting task. It included in its ranks both moderate and hardline Muslims. Among the latter were people such as Ahmad Sumargono of KISDI. In the final years of the Soeharto regime, Sumargono had developed a reputation as a Soeharto supporter who was also vehemently anti-Chinese and anti-American. KISDI had long propagated the view, discussed above, that the United States, Israel, and the Vatican were intent on destroying Indonesia. Sumargono and his party (the $\mathrm{PBB}$ ) had secretly begun to coordinate their opposition to President Wahid less than a month after his inauguration. According to these same sources, Sumargono was aided in these efforts by General Wiranto, who sat in the Wahid cabinet, although he was to be forced out two months later.

Clearly, then, Wahid faced a Herculean task in attempting to keep this coalition together. However, proposals Wahid made early-on in his presidency made matters worse. Although his party had won just 11 percent of the vote, Wahid felt confident enough to disregard his Muslim allies by proposing that Indonesia open diplomatic relations with Israel. He also announced that he proposed to take measures to lift restrictions on the Communist Party. Both proposals sent shock waves through the conservative and moderate Muslim communities. Coupled with the firing of several cabinet officials linked to his 
allies, as well as Wahid's intemperate habit of commenting on friends and enemies alike with flippant irreverence, Wahid quickly alienated moderate and conservative members of his coalition. Unable or unwilling to mount an effective campaign to control the violence in Maluku, Wahid unwittingly contributed to the political evisceration of moderate Islam.

\section{The future of the Islamic parties and Golkar}

However much the Islamic parties (with the exception of the NU-linked PKB) might have benefited from the downfall of Abdurrahman Wahid, their future in Indonesian politics is still far from certain. Despite the appeals of some conservative Muslim leaders, there seems little chance that the conservative Muslim parties will unite to form a single party. The leadership of the bigger Muslim parties has been plagued by factional disputes and allegations of corruption. Megawati Sukarnoputri's secular-national Indonesian Democratic Party-Struggle has also been plagued by similar problems. In addition, Megawati's unengaged style as president has alienated many of her former supporters. Barring some unexpected development, however, her nationalist party remains the most attractive electoral vehicle for those Indonesians who continue to believe in the idea of a multireligious and non-confessional (i.e., non-Islamist) state. The conservative Muslim vote, by contrast, is likely to remain split among several competing parties.

Although earlier discredited through its close association with President Soeharto, Golkar, the country's former ruling party, shows signs of expanding its electoral support. Although electoral predictions lie outside the charge of this report, the author would venture to guess that, barring some unforeseen development, the 2004 elections will see these two parties, Golkar and the PDI$\mathrm{P}$, again emerge as the dominant ones. Indeed, in light of the problems the PDI-P has faced in consolidating its national organization, Golkar may be able to expand its share of the vote slightly at the expense of the PDI-P.

It is too early to predict the likely outcome of the 2004 elections. Election results aside, one can make the following observations about the major Muslim parties:

- PPP: The only official Islamic party during the Soeharto New Order (after 1971), the PPP or United Development Party still has the most sophisticated national organization of all large Islamic parties. It has also benefited from the fact that the party's chief, Hamzah Haz, serves as vice president to Megawati Sukarnoputri. The PPP rank and file have a diverse ideological profile, ranging from ultraconservative supporters of jihad to moderate conservatives with a background in NU. The vice president himself visited Jafar Umar Thalib of the Laskar Jihad shortly after his second arrest, in May 2002. However, what unites the party is 
its official commitment to changing the constitution and making Islamic law the law of the land for Muslims. This PPP proposal, made jointly with the more conservative $\mathrm{PBB}$, made little headway in parliament. But the campaign worked to solidify the PPP's image as a bastion of pro-Shariah Islamism. The PPP constituency consists primarily of people from the conservative wings of NU and Muhammadiyah, and these Muslims view implementation of Islamic law as a priority. Although survey information is lacking, anecdotal evidence from the regions suggests that the campaign for Islamic law has made only minor headway among other segments of the Muslim populace as well.

While the PPP has managed to maintain and even expand its base since the fall of Soeharto, it was shaken in late 2001 by fierce factional fighting and the defection of some of its most popular spokespersons to a new, "reform" PPP. At the moment, the reform PPP lacks an effective national organization, and its future does not look promising. If the new party weakens the original PPP's appeal at all, the damage will likely be only modest. The PPP's impressive national organization, militant cadres, and hold on the vice presidency ensure that it will likely remain the strongest of the Islamic parties. It may well increase its share of the vote in the 2004 elections, by some estimates to 15 percent of the total. The party also enjoys a competitive advantage over its rivals because it has a solid following among both ethnic Javanese (who make up 45 percent of the country's population) and nonJavanese.

- PKB: Although most of its supporters come from the moderate and democratic wings of the Nahdlatul Ulama, Abdurrahman Wahid's PKB is officially a multireligious party. The party benefited from a momentary influx of funds from business patrons during the first months of the Wahid presidency. However, since Wahid's removal from the presidency in July 2001, the party has been plagued by bitter factionalism, poor management, and a chronic lack of funds. Many observers believe that the PKB's share of the overall vote may decline a couple of percentage points from the 11 percent obtained in the 1999 election. The party does not appear to have made significant headway in its goal of recruiting non-Muslims to its ranks. It also has not managed to establish a solid party apparatus outside of its areas of historic representation in East and Central Java. Even within the party, critics have faulted Wahid for being unwilling to share power and encourage the regeneration of the party's leadership. 
During the fall of 2001 and early 2002, the party was also split by a bitter factional feud, pitting Wahid and his ally, Alwi Shihab (the former foreign minister), against the party's former leader and minister of defense in Megawati's cabinet, Matori Abdul Djalil. During the maneuvering leading up to Wahid's removal in July 2001, Djalil threw his support to Megawati. The party has also recently split over the question of whether it should support Abdurrahman Wahid for the presidency in 2004. Wahid has signaled that he is determined to run; even mainstream PKB officials fear that the effort could do serious damage to the PKB.

In short, although the Nahdlatul Ulama remains a critical institution in Muslim Indonesia (see below), the PKB does not appear well prepared for the next round of electoral competition. In April-May 2002, however, Wahid surprised the political elite with a variety of maneuvers that enhanced the PKB's influence in the parliament. Megawati Sukarnoputri's deal-making husband, Taufik Kiemas, paid a respectful visit to Wahid at this time. Although a reconciliation between the PDI-P and the PKB remains unlikely, some small increase of coordination before or after the 2004 elections is not out of the question. Over the long term, the PKB will likely survive Wahid, however, perhaps as a second-tier national party, and still one of the larger among the Muslim parties. The party has a new generation of young, democratic Muslims coming up in its ranks, and and remains the most pluralist and democratic of all the major Muslim parties (by far). Despite the mis-steps of the Wahid presidency, the PKB's role as a defender of a pluralist Indonesia and a moderate Islam seems likely to survive the post-Wahid era.

- PAN: Of all the Islamic parties, Amien Rais's PAN has changed the most since its founding in 1998. At that time, Amien Rais boldly sought to use the party to break out of his exclusive identification with the Muhammadiyah community and position himself as a pluralist and democratic leader. His advisors reported (in interviews in 1999) that the poor showing of his party in the elections ( 7 percent of the vote) so shocked Rais that he felt obliged to steer away from PAN's original platform and reposition himself again squarely in the modernist Muslim communityindeed, in a segment of the Islamic community that was considerably more conservative than the constituency toward which he had originally directed his appeals. While effecting this ideological reorientation, the PAN leadership has also sought to expand its mass base across the country, primarily by linking the party to already established Muhammadiyah networks. 
Unlike the PKB, PAN appears to have made significant progress in its program of party consolidation. Although a significant proportion of the Muhammadiyah rank and file still give their support to Golkar, the PPP, or even the PBB, the effort at party consolidation has worked well enough that many observers believe that PAN will increase its share of the vote in 2004perhaps to as much as 10 percent of the vote, on a par with what the PKB may earn.

However, barring some unexpected shift, it is unlikely that PAN will shift further toward conservative Islamism, for example by advocating the full implementation of Islamic law. However much the party has turned away from its earlier pluralist platform, it seems likely to remain a moderate or moderately conservative force on the Muslim political scene-less pluralist and Westernfriendly than the PKB, but moderate nonetheless. If Golkar continues its outreach to centrist Muslims, it is conceivable that Golkar and PAN could form an alliance. However, Golkar's interest in such a union could be mitigated if it sees a greater interest in collaborating with Megawati's Democratic PartyStruggle or, alternatively (and less likely), radical Islamists.

- PBB: The Party of Moon and Stars or PBB is, at least in its senior leaders' eyes, the direct heir of Masyumi, the largest of Indonesia's Islamic parties in the 1950s. Having won just 2 percent of the vote in 1999, however, the PBB legacy does not appear to impress most Muslims. The party has long been identified with militant hardliners such as Ahmad Sumargono and Eggy Sudjana, undercutting its support in the moderate middle class. Equally serious, in 2001 the party was split by a factional feud between Yuzril Mahendra, the more moderate leader of the party main's faction, and old-guard radicals linked to hardline groups such as KISDI and the DDII. Although the split coincides with a serious ideological divide in the party, it was provoked as much by financial arguments as by ideological ones. (The old guard accused Yuzril of failing to share a portion of the funds that the Habibie government provided to the party).

Although unlikely to increase its share of the national vote significantly, the PBB may well remain a fixture on the Muslim political scene, especially because of its hold on KISDI, Dewan Dakwah, and the Masyumi legacy itself. But it does not at this point appear at all likely to transform itself into an effective mass organization. In interviews with PBB members in Yogyakarta 
during July-August 2001, many told me that they expected to shift their allegiance to the PPP in the 2004 elections. Some PBB activists have even proposed fusing the party with the PPP.

- PK or Justice Party: The Justice Party won less than 2 percent of the vote in the 1999 elections, but the party exercises an influence on Muslim politics greater than its share of the vote alone. The party's cadres are recruited from the ranks of Muslim campus activists, especially those associated with the moderately conservative but idealistic Islamist group, KAMMI. Although strict in matters of faith and conservative in its interpretation of Islamic law, KAMMI activists, like the PK, tend toward moderation in their actions. Interviews conducted with KAMMI and PK activists in Yogyakarta in 2001 indicated that many were still concerned that the jihad fighters were being "manipulated" by a third force, hinting at possible military involvement.

Like KAMMI, the Justice Party is officially committed to implementing Islamic law in Indonesia. Rather than using paramilitaries to realize this goal, however, the party insists that the Indonesian people must prepare for the change through longterm social and religious education. In these and other ways, the Justice Party is, tactically speaking, relatively moderate in its actions, even if its commitment to the implementation of Islamic law places it toward the conservative end of the Muslim ideological spectrum. The PK's rank and file are the most disciplined and uncorrupt of all the major Islamic parties. They are also the youngest, however, and defections seem likely to continue as members age and opt to affiliate themselves with better established political parties. Despite these handicaps, the PK is well positioned to continue to exercise a significant intellectual influence on national politics, even if its share of the vote increases by only one or two percentage points in 2004.

As this brief survey implies, the Islamic parties may well increase their total share of the electoral vote in 2004, although their total gain may still be limited. Leaving the PKB to the side (because, ideologically if not in terms of membership, it remains a nationalist party), these Islamic parties won about 16 percent of the vote in 1999. Their share of the vote in 2004 may well increase to 20 or 22 percent. The PPP and PAN may well enjoy the lion's share of this increase. Nonetheless, it is highly unlikely that any single Muslim party or even a coalition of Muslim parties will emerge as the leading vote-getter in the 2004 elections. If Golkar and the PDI-P remain the two main parties, the greater likelihood is that the Islamic parties will play a role not unlike that in the 
Wahid and Megawati era. That is, they will wield influence by striking deals and forging coalitions with the larger parties.

The great unknown: Golkar and the Muslim parties. Perhaps the most serious question with regard to the future of Muslim party politics concerns not the explicitly Islamic parties, but Golkar. As noted above, Golkar has survived the trauma of the transition from the Soeharto era, and successfully maintained and impressive national organization. It remains the dominant party outside Java. It also exercises significant political influence by virtue of its continuing popularity among government bureaucrats. This could change. However, for the moment, the lack of a viable alternative to the party seems likely to ensure that Golkar will remain a key player on the national scene. It is not unlikely that the party will improve its share of the national vote in 2004, perhaps edging up to or even exceeding the share earned by the PDI-P.

If this proves to be the case, a major question for the future of Muslim politics will be whether the pro-Islamist faction in Golkar gains the upper hand, or whether the Muslim-dominated but pluralist wing of the party prevails. The Golkar leadership today is dominated by individuals of a moderate Muslim background, as epitomized by the current party leader, Akbar Tanjung. Tanjung has a background as a moderate leader of the Islamic Students Association, or HMI. The Golkar leadership's actions in recent years suggest that it is not driven by a deep commitment to any particular ideology, notwithstanding a few ideological "givens," such as virulent anti-communism. As long as this leadership controls Golkar, the party's future direction will likely depend less on ideology than on opportunities for alliances with either the PDI-P or a fractious assortment of Islamic parties (a coalition unlikely to include the $\mathrm{PKB}$ ).

There is, however, a more ideological, and notably anti-American, faction in Golkar, organized aroundsupporters of Din Syamsuddin, the former director of Golkar's secretive research and development bureau. While this group's overall influence in the party is not great, its behavior after September 11 shows that it might well attempt to take advantage of political crises to catapult itself into a leadership position (see below).

\section{The future of major Muslim social associations}

For students of Muslim politics and society, Indonesia has always enjoyed a special distinction in the Muslim world because it is home to the largest (by far) Muslim social and educational organizations in the world. Although lacking a fully effective and modernized organization, the Nahdlatul Ulama has 35 million followers and reaches into the farthest corners of Central and East Java. It has a limited presence in a few other provinces, such as South Kalimantan. The national elections in 1999 revealed that the organization's 
members are often reluctant to heed the instructions of their leaders when it comes to political matters. The NU rank and file distribute their vote to a wide variety of political parties, not least of all the PPP and PDI-P, in addition to the PKB. NU conservatives vote for the PPP, and nationalists of social-democratic inclination give their vote to the PDI-P.

The modernist Muhammadiyah claims to have some 25 million followers. This organization enjoys a more disciplined, better educated, and more committed membership than the NU. Nonetheless, the results of the 1999 elections show quite clearly that, on political matters, the Muhammadiyah membership does not act as a bloc. However, the organization's single largest faction remains moderate. Although Muhammadiyah does have a conservative and even hardline wing, it does not have a secular social-democratic wing, as does the NU.

Forces for moderation Despite their relative lack of political cohesion, these two organizations remain vitally important to the future of Indonesian Islam. They deserve to be at the center of any U.S. policy aiming to engage Indonesian Islam and strengthen pluralism and tolerance in the country.

However varied their individual membership, together these two organizations exercise a powerfully moderating influence on Muslim society and politics. Among other things, both organizations have a well-established tradition of organizational autonomy relative to the state and political movements. Except for their participation in the mass killings of 1965-1966 (in which all major parties, including Hindus and some Christians, participated), both have also consistently rejected Islamist extremism. In these and other regards, these two organizations provide a strong institutional precedent for the idea of civil society and of a countervailing balance of powers in state and society. Muslims of democratic inclination cite these precedents when arguing that there is an already existing, if incomplete, social capital for civil society and participation in this Muslim society. The Muhammadiyah and NU provide just such precedents. Indeed, they arguably remain the most exceptional civic organizations in the Muslim world.

Both organizations also provide an important precedent for Muslim involvement in welfare, educational, and community activities-apart from national politics. Rather than being a limitation, the social or civic emphases of these organizations are advantageous. They have helped to show Muslims a way of pursuing practical goals in a civil and participatory manner outside of formal politics. Both the Muhammadiyah and Nahdlatul Ulama weathered the political storms of Dutch colonialism, the Japanese occupation, the war for independence, and the early independence period by working to safeguard what most of their rank and file regarded as their organizations' crown jewels: their network of social and educational institutions. 
This practical involvement in community life also has an ideological benefit. It has helped to demystify the appeals of Islamist utopians who would reduce Islam to the struggle to implement "shariah" (Islamic law), as if the law was a panacea for all social and cultural ills. Muhammadiyah and Nahdlatul Ulama provide vivid demonstrations of the fact that Muslims can respond, not to abstract renderings of their religion, but to the real-world effort to improve the lives, welfare, and decency of ordinary people.

Ironically, the location of these two remarkable organizations in civil society is also the main source of their weakness relative to Islamic extremism. The NU and Muhammadiyah are both social, educational, and welfare organizationsunambiguously so. They are not political parties organized to maximize their influence in political society; nor have they ever been organized to respond to external threats, whether from secular opponents or Islamic extremists. While clear-headed and consistent on matters of religious doctrine, both organizations tolerate a great range of opinion on matters of politics and party affiliation. Both organizations, especially the Muhammadiyah, regard politics as something distinct from organizational interests, and best left to the discretion of individual members.

In light of their ideological diversity and organizational charge, both of these organizations have had difficulty responding to the sudden upsurge in Islamic extremism in Indonesia since 1998. Their inability to formulate a quick, coherent response has been complicated by the fact that extremist propaganda concerning violence against Muslims in Maluku, Central Sulawesi (Poso), and Central and Western Kalimantan (involving Christian Dayak killing of Muslim Madurese) has effectively outpaced the propaganda of the moderates in its detail, technological sophistication, and mass-media distribution. International assistance in the field of mass communications, especially the worldwide web, would be a low-cost investment that might greatly assist moderate Muslims' efforts in these fields. A heightened presence on the worldwide web would also allow moderate Indonesian Muslims to disseminate their ideas to the international Muslim community.

Even a quick search of Indonesian internet sites on the violence in Maluku reveals that, aside from a few sites identified with Christians (including some based in Europe and the U.S.), most of the coverage is provided at sites operated by Islamic radicals. Worse yet, from 2000 on, even mainstream newspapers and magazines in Indonesia have been polarized on the question of Muslim-Christian violence.

The polarization was exacerbated, it should be noted, by the enormity of the violence perpetuated on Muslim civilians by nominally Christian gangs in several awful incidents at the end of 1999 and again in 2000. One of the most infamous incidents involved the slaughter of several hundred women and 
children taking refuge in a mosque in northern Halmahara (in North Maluku) at the end of December 1999. Some people have speculated that the worst of these Christian attacks may have been deliberately provoked by regional gangsters and local military bosses, who wished to inflame Muslim passions. However, even if this was the case, and the evidence is unclear, what is lamentably apparent is that many Christians eagerly participated in the killing of innocent Muslim civilians.

Radical Islamists took immediate advantage of the propaganda opportunities provided by such heinous attacks. Under these circumstances, only the most courageous Muslim leaders felt it worth their while to appeal for calm and moderation. It should be noted that Syafii Maarif of Muhammadiyah and Abdurrahman Wahid of NU, were consistently among those appealing for peaceful resolution of the violence.

\section{The need for assistance: NU}

Both of these pivotal organizations now face serious challenges, and could benefit from Western European and American assistance. The Nahdlatul Ulama is still suffering from the shock of Abdurrahman Wahid's sudden removal from the presidency in late July 2001. The disorientation has been exacerbated by the fact that, although the most pluralist wing of the NU has long sought to forge an alliance with Megawati's PDI-P (and the secular nationalist community generally), many NU leaders, including Abdurrahman Wahid himself, are convinced that Megawati betrayed Wahid and the national constitution. Speaking at the end of February 2002, Abdurrahman Wahid again reiterated this view However, during Wahid's visit to Boston University in May 2002, he showed a considerable softening of views on both Megawati and the U.S. role in his ouster.

Wahid has long had a tendency to take personal affronts seriously. His irritation with Megawati may yet impede efforts to reconstitute a grassroots reform coalition-if, that is, Megawati's PDI-P is interested in renewing such an alliance. Most Indonesian observers believe that Megawati has developed a deep dislike of Wahid. Still, alliances in Indonesia occasionally have an ability to overwhelm personal considerations, and something like this may yet happen between Megawati and Wahid. Despite these personal tensions, the meeting between Taufik Kiemas (Megawati's husband) and Wahid in May 2002 suggests that the PKB's and NU's relationship to the nationalist community in the PDI-P may yet be repaired, if not fully reconstituted.

Ironically, this tension between Wahid's political ambitions and the broader circumstances of NU's less politically inclined activists may work to the Muslim organization's benefit-and provide a point of entry for international and U.S. assistance to this vital organization. Many young NU leaders express 
dissatisfaction with Wahid's stated intention to run for the presidency in 2004. The most democratic among the new generation of NU leaders also express deep misgivings about Wahid's interest in tying the NU's fortunes so closely to its sister party, the PKB. Many would prefer to see a return to NU's original 1926 khittah or platform, which insists that the organization remain distant from party politics. This interest on the part of the young NU leadership is not just a matter of ideology. NU was never primarily a political organization. Its primary mission, embraced by most of its rank-and-file, remains education and social welfare. The fact that so many young NU leaders are uninterested in sacrificing this mission to political ambitions suggests that there is a good opportunity for international and American aid agencies to renew collaboration withthe organization, especially in the fields of education, health, business development, and communications. Such programs could strengthen the moderating influence of this organization in society, and provide a countervailing influence to radical Islamism.

\section{Muhammadiyah's challenge}

The situation in the Muhammadiyah is similar, but its internal cleavages are far more serious - and politically charged. Under the leadership of Syafii Maarif, a $\mathrm{Ph} . \mathrm{D}$. in political science from the University of Chicago, the Muhammadiyah in the post-Soeharto period has embarked on what is, in comparative Islamic terms, a breathtaking program of cultural and educational reform, aimed at liberalizing Islamic theology and practice in a manner consistent with democracy, human rights, and pluralism. The key doctrinal body in the Muhammadiyah is a small group known as the Majelis Tarjih. Packed with democratic-minded individuals appointed by Maarif, this body has outlined a program of reform that is among the most enlightened of any mainstream organization in the Muslim world. Keenly aware of the opposition that such bold programs might excite among Muhammadiyah conservatives, Maarif's group has only quietly pushed these reforms. However, their impact has already been keenly felt among younger Muhammadiyah associates.

Unfortunately, the Muhammadiyah is factionalized: Maarif's democratic group is pitted against a conservative faction with ties to Islamic hardliners, under the leadership of Din Syamsuddin (see above). At a time when Syamsuddin was still widely viewed as discredited by his association with Soeharto, he surprised his Muhammadiyah colleagues by running for the chairmanship of the organization in August 2000. To the great surprise of Maarif group, Syamsuddin came within ten percentile points of Maarif's share of the vote. Had the Golkar portion of the vote not been divided, Syamsuddin might have won.

Since the election, Syamsuddin has been tireless in his campaigning around the country to expand his base of support. From his position as secretary of 
the semi-governmental Council of Indonesian Muslim Scholars (MUI), he coordinated opposition to President Wahid, provided quiet counsel to the jihad fighters, and worked to strengthen his support among rank-and-file Muhammadiyah members. The Muhammadiyah will elect a new chairman in 2005, and many people are betting the new leader may be Syamsuddin.

American assistance to or cooperation with the Muhammadiyah, if any, must be handled in a delicate manner

- There is a small but vocal minority in the organization that opposes cooperation with any Western agencies . This group would be all too willing to take advantage of American mis-steps toward Maarif to discredit the moderate leader. At the same time, however, there is a younger generation of Muhammadiyah activists who share Maarif's pluralist vision and who are eager to expand educational opportunities for Muhammadiyah youth. They also want to strengthen the organization's commitment to public welfare and social justice. These broad interests offer critical opportunities for collaboration with U.S. and international agencies.

\section{Revitalizing the Islamic university system}

No discussion of Muslim social associations and intellectual trends would be complete without mention of the state-sponsored Islamic university system. Historically known as IAIN, or State National Islamic Institutes, the IAIN are scheduled over the next few years to be upgraded to a status equivalent to nonreligious state universities. (The program has slowed owing to the country's economic crisis, but it is still underway.) Their official titles will change from IAIN to Universitas Islam Indonesia. The upgrading will entail many reforms, but the most dramatic of these will involve the expansion of the curriculum to include many secular, professional programs, as well as training in social sciences and the humanities.

This change will have a far-reaching impact on the future of Islam in Indonesia, and is likely to be a matter of considerable debate. Each year the IAIN system graduates Islamic scholars with diverse specialties in Islamic studies. Since the 1990s, the overall impact of IAIN graduates on Indonesian Islam has been unequivocally positive, strengthening the pluralizing stream in the Muslim community. The most publicly influential intellectuals writing on the challenges of pluralism and democracy in Indonesia today are not secular academics, but graduates of the IAIN.

Inasmuch as the IAIN system is just beginning its program of educational upgrading, there is a need and opportunity for international and Western aid agencies to "get in on the ground floor" and strengthen the efforts of those who wish to see the reforms implemented in a way that enhances moderate Muslim aspirations for pluralism, civility, and democracy. Many of the best 
students are keenly interested in studying Western social sciences and humanities, including political science, political and moral philosophy (not least of all as concerns democracy and society), sociology, and comparative religion. Again and again, research in Indonesia has indicated that Muslims trained in history, economics, and the social sciences tend to be pluralist and moderate in political disposition. By contrast, graduates from the technical and medical sciences tend to be conservative or even fundamentalist in disposition. Aid programs that strengthen Muslim students' training in the social sciences, and requiring students in the natural and technical sciences to take a few such courses, could well enhance the forces of moderation among Muslim students, and provide Indonesia with a generation of thinkers willing and able to face the challenges of the modern age. 


\section{Indonesia's relationship with the United States, and regional and global initiatives}

Any survey of the impact on trends in Islam on Indonesia's relationship with the U.S. and Indonesia's Southeast Asian neighbors must begin with a comment on the Indonesian authorities' reactions to charges that Al Qaeda operatives have been operating in Indonesia. Recently some Indonesian analysts have speculated that the Laskar Jihad may have ties to bin Laden's Al Qaeda. In interviews with journalists, Thalib has admitted that he has been visited several times by Al Qaeda representatives, even as recently as May 2001. In interviews, however, Thalib has firmly denied reports that Al Qaeda fighters have recently traveled to Maluku to join the battle against Christians. He and his spokespersons were outraged when, in late September 2001, Al Chaider, a prominent militant from a more moderate wing of the Darul Islam, claimed that bin Laden agents had supplied the Laskar with $\$ 240,000$ and several dozen Arab fighters. Laskar officials issued an immediate and fierce denial.

The issue of $\mathrm{Al}$ Qaeda links did not end there. In the late fall of 2001, Western journalists traveling in Sulawesi reported seeing Afghan and Arab fighters. On December 12, 2001, Indonesia's intelligence chief, Lt. General Abdullah Hendropriyono confirmed these reports, commenting that Al Qaeda had established a training camp in Indonesia and was assisting jihad fighters in Maluku and Central Sulawesi. The next day the minister of defense, Matori Abdul Djalil, expressed full confidence in the validity of Hendropriyono's comments. Court documents related to the arrest in November of Al Qaeda agents in Spain also seemed to confirm the allegations, including photographs of what were said to be Al Qaeda camps in Indonesia. However, angry at Hendropriyono's comments, conservative Muslims, including the secretary of the Indonesian Council of Scholars (Din Syamsuddin, the same man who had helped coordinate the Council's call for jihad against the U.S.), accused Hendropriyono of being "one sided" and doing the bidding of the United States in making these accusations. In the face of this fierce public outcry, Hendropriyono backed away from his charge three days later. He claimed that he had been "misunderstood," and insisted he had never said that Al Qaeda had a cell in Indonesia or that the Laskar Jihad was linked to it.

Several insights can be distilled from this incident. First, although Thalib has recently condemned Osama bin Laden, senior aides interviewed in August 2000 expressed repeated enthusiasm for Osama bin Laden's campaign against the United States. Thalib's recent public distancing from bin Laden, then, may well owe as much to tactical considerations as religious ones. Where Thalib and his followers take greatest exception with bin Laden is not on the mass killing of innocents in the United States, but on bin Laden's opposition to Saudi Arabia. For Thalib, bin Laden's opposition to a state that enforces 
Islamic law marks him as a "Khawarij" rebel. The phrase refers to the "exiters" who dissented from the followers of Ali at the end of the seventh century C.E. and promoted what has come to be regarded as a rebellious and ultraegalitarian Islam unacceptable to the Sunni mainstream.

A second point is equally important. Whatever his Middle Eastern connections, it is clear from the above discussion (section 2) that there are sound political reasons for Thalib to publicly repudiate Al Qaeda. Since the establishment of the Laskar Jihad in early 2000, Laskar Jihad initiatives have been vitally dependent on domestic backers, particularly a faction of the armed forces and armed forces retirees. Although deeply committed to his conservative vision of Islam, Thalib has shown himself to be an astute politician, not a fanatical ideologue. In interviews during August 2001, he made clear that he is keenly aware that, without this assistance, he would not have been able to catapult his once-marginal organization onto the national stage. On the basis of this and other evidence, Thalib's distancing from bin Laden appears to have more to do with his determination to maintain good ties with his allies as it does any misgivings about bin Laden's actions against the United States.

\section{The evidence on Al Qaeda connections}

Notwithstanding some claims to the contrary, there is no credible evidence at this point indicating that Thalib has received aid from or coordinated activities with bin Laden. Conversely, it is clear that Thalib has received extensive funding from domestic backers. Equally important, whatever his ideological ideals, Thalib clearly wants to have an impact on Muslim politics in Indonesia. No matter how aggressive his actions in Maluku or his propaganda against Christians and the U.S. are, he is less utopian in his ambitions than, say, the inner-circle leadership of the Majelis Mujahidin Indonesia. Indeed, all evidence indicates that Thalib himself is responsive to pressures emanating from his allies and from the domestic political environment generally.

This same observation applies all the more to the leadership of the Islamic Defenders' Front, or FPI. More than any of the other Islamist paramilitaries, the FPI depends heavily on support from backers in a segment of the military (including retirees) and civilian bureaucracy. Although its leaders are fiercely anti-American, the organization's leaders have also shown themselves keenly responsive to economic incentives, including those related to their organization's involvement in protection rackets and extortion. There is no evidence suggesting that this group is linked to international terrorist networks. Secret contacts cannot be ruled out, however, not least because some of the FPI leadership has active family ties to people in Yemen. 
The situation is quite different for the third of the paramilitaries discussed here, the Majelis Mujahidin Indonesia. As noted above, the official leadership of the MMI is varied, and includes some conservative advisors like the Cornelltrained Deliar Noer. Noer is clearly opposed to violence and extremism. However, even more than the above paramilitaries, the MMI's structure appears to distinguish between public representatives and inner core of leaders.

Moreover, the evidence that some of the inner leadership of the MMI have had ties with Al Qaeda seems credible. As noted above, two inner-circle leaders, Abu Bakar Ba'asyir and Hambali, have been accused by Malaysian, Singaporean, and Philippines authorities of having direct ties to Al Qaeda operatives. These accusations are certainly consistent with anecdotal reports circulating in central Java prior to September 11, 2001, to the effect that the Surakarta wing of the MMI had extensive international ties, including some to Al Qaeda.

If such linkages do exist, effective policy intervention will require that Indonesian authorities and the United States take care not to play into the hands of the Jemaah Islamiyah cell in the MMI. Abu Bakar Ba'asyir has already shown great skill in appealing to nationalist sensibilities against the United States. Appeals to nationalist pride will be the primary card he plays if and when further actions are attempted against him. In this regard, it is sobering to reflect on the lessons of the much-needed but mishandled attempt to take action against terror suspects in December 2001, discussed above. The fact that security chief Hendropriyono was forced to back away from his public accusation speaks legions to the problem faced by officials who wish to mobilize sentiment among the political elite against extremists.

These and other incidents, such as the public reaction to the Joint Battalion's attack on the Laskar Jihad in June 2001, show that radical Islamists can effectively appeal to injured national pride so as to deflect efforts to subject them to investigation. The incidents also show that, however much Indonesia's intelligence services might wish to take action against these groups, others in the armed forces may still be reluctant to do so.

\section{The need for transnational cooperation against terror and for an ASEAN role}

In the months to come, then, one of the most effective instruments with which to leverage Indonesian public opinion and back up the efforts of security officials interested in taking action against terrorism may well be enhanced Indonesian collaboration with security officials in Singapore, Malaysia, and the Philippines. The fact that officials in these three countries broke with the ASEAN custom of non-interference in other countries' affairs and called for 
the Indonesian government to take firm action against the Jemaah Islamiyah caused great surprise in Indonesia, and added to the credibility of the claim that Al Qaeda is operating in the country. Of these three countries, Singapore's influence is perhaps the weakest, since Singapore is seen as a close ally of the United States. The Philippines' influence is somewhat compromised-but not greatly. Despite the fact that U.S. Special Forces are now operating in the southern Philippines, Indonesian citizens and officials historically have a high regard for the Philippines, and take their Christian neighbors' views seriously. The same is even truer for Malaysia. Although Prime Minister Mahathir's reputation has been damaged by his punitive actions against Anwar Ibrahim (a man who was widely respected in Indonesia) in 1999, he is still regarded as a serious Muslim proudly intent on maintaining his country's independence in foreign affairs. Hence his government's claims weigh heavily on Indonesian public opinion.

ASEAN does not have a demonstrated record of achievement when it comes to issues such as effective military cooperation. But its leaders have been able to exercise subtle moral influence across national borders. The efforts of ASEAN leaders, including (but not limited to) the leaders of Malaysia, the Philippines, and Singapore, may well be one of the most effective ways to shift the balance of elite opinion in Indonesia, and give moderate voices an edge.

Conversely, direct military pressure from the United States on Indonesia is likely to backfire. It is ceretain to be exploited by Islamist radicals and their supporters in the military. The key to an effective American strategy lies in enhancing the political influence of moderates in the Indonesian armed forces and bureaucracy. With the near-collapse of the secular nationalist leadership in the final years of the Soeharto regime, moderate commanders have had to lie low whenever a dispute has arise concerning Muslim politics. The key to empowering these actors again lies in allowing them to demonstrate that they are true to the best ideals of Indonesian nationalism and Indonesian Islam. The elections of 1999 showed the deep reservoir of moderation that exists in the Indonesian Muslim community. But the well-coordinated actions of extremists caught the moderate mainstream off guard.

\section{The U.S. role: some options}

Given the factionalized state of the political and military elite, U.S. influence may be most effective if it is extended through several channels simultaneously, rather than one. This report earlier highlighted two key areas where U.S. assistance could begin immediately, with great effect and in a cost-effective manner: 
1) Assistance to Muhammadiyah and Nahdlatul Ulama for educational and welfare programs. Aid to the former organization would have to be provided with transparency and discretion, so as not to invite attacks from the small but vocal hard-line wing in this organization opposed to cooperation with the United States. Aid to the NU, by contrast, can be provided more easily_although it may require some mending of U.S. ties with Abdurrahman Wahid.

Aid assistance might focus on (a) aid to schools to help in expanding their curricula and professional training, (b) women's health and education, (c) media skill training, including upgrading of educational outreach through the worldwide web, and, very important, (d) basic training in business and market-oriented economics (see below).

(2) Targeted assistance to the Islamic University System (IAIN). Now in the process of being placed on an academi par with the national university system, the IAIN system is adding new technical, social science, and humanities concentrations to its curriculum. Already in the 1980s, the IAIN exercised a powerfully moderating influence on Indonesian Muslim politics. This influence could be strengthened through targeted assistance for program development, as well as scholarships for study in the United States. Areas of particular emphasis should include courses in law (Western and Islamic) and political philosophy, in which Muslim intellectuals have a great interest; political science and political sociology, especially regarding the conditions that make democracy and markets work; journalism; comparative religion and religious history; and professional and technical training that includes exposure to the liberal arts (this is very important).

In addition to these immediate areas of assistance, several others might be mentioned.

(3) The need for business and market education. One of the deficiencies that has most struck observers of Muslim society in Indonesia in recent years has been the startling lack of sound knowledge about the basic principles of business and market economics. Although in the 1950s the Muslim middle class was known for its business acumen, the Muslim leaders today (see above) come from a background in religious organizations or government, not business. They have an only vague understanding, at best, of market processes. The mainstream view is one strongly influenced by dependency theory and a crude Marxism, laced with more specifically Islamic anxieties about globalization, Jewish financiers (Soros, and so on), and baneful cultural influences such as pornography. Certainly 
concerns like pornography are legitimate, as is the anxiety that a flood of Western films and television programs might have a less than salutary influence on young Muslims. By being sensitive to these concerns end emphasizing that one can support market capitalism without giving up one's own cultural identity, Western donors could do a great service to Indonesia and Indonesian Muslims.

Programs targeted at enhancing specific business skills could also enhance Muslim participation in small and medium enterpriseshelping, over the long run, to mute tensions between Indonesian Muslims and the Chinese Indonesians who otherwise dominate largescale enterprise.

(4) Engaging a factionalized military. It is not the charge of this report to analyze the Indonesian military or recommend policies for its future. However, in the course of discussing Muslim extremism, it becomes clear that a faction within the army and among army retirees has played an extensive role in providing assistance to Islamic extremists, including two organizations (the Islamic Defenders Front, or FPI, and the Laskar Jihad) that are stridently anti-Western . At the same time, the actions of police and military commanders in Maluku, Sulawesi, Java, and Jakarta, among other regions, have repeatedly demonstrated that many officers have deep misgivings about the Islamist paramilitaries, and regard their colleagues' collaboration with these groups as mistaken. More recently, the commanders of the intelligence services appointed by President Megawati Sukarnoputri have attempted to raise public awareness of the threat of international terrorism in Indonesia.

These actions suggest that there is still a reservoir of patriotic nationalism, as well as simple self-interest, in the armed forces that can be engaged by foreign governments. In light of the unsettled state of the Indonesian armed forces, their past (and, alas, continuing) history of human rights abuses, and the scale of ongoing regional conflicts, the immediate and unconditional provisioning of arms might send the wrong signal to the Indonesian command.

Still, enhanced engagement with the Indonesian armed forces and intelligence services must be regarded as a priority for any American policy that attempts to diminish the chances of radical violence in Indonesia and restore peace, security, and civility. Without the latter conditions, moreover, the prospects for restarting Indonesia's stalled transition to national stability and some measure of democracy remain slim. In this regard, I believe that it is imperative to make every effort to reopen the dialogue with members of the Indonesian armed 
forces. Events of the past three years oblige us to recognize that, rather than enhancing the prospects for professionalism in the military and for civilian control over the armed forces, the continued shunning of Indonesian military commanders has only worked to strengthen the hand of that faction intent on promoting an antiWestern, anti-American, and, for some, anti-Christian agenda. The war against international terror, the survival of a united Indonesia, and the strengthening of moderate Islam all recommend a different course of action based on engagement rather than continuing exclusion.

To be effective, the effort will require considerable diplomatic finesse. If engagement is to succeed at containing those in the armed forces willing to work with extremists, it should from the start signal to Indonesian authorities that those who discredit their uniform and nation will not be allowed to participate in this dialogue, or in collaborative activities such as intelligence sharing or training programs. In addition, the engagement should be made subtly conditional-subtle in the sense that the conditions are not broadcast to the rest of the world (or the Indonesian public), but conditional in the sense that progress toward further collaboration will depend on achievement of specific policy aims.

The two best services with which to begin this dialogue appear to be the intelligence services and the police. The police are, certainly, factionalized. In some, indeed most, regions, they are also involved in protection rackets and crime. The authors of the recent ICG report, "Indonesia: The Search for Peace in Maluku" (2002) come to the conclusion that some members of the army and police may be abetting the outbreak of violence in that troubled province, so as to provide themselves with greater opportunities for protection income. Despite these sobering reminders, the police leadership, having recently separated from the armed forces, wants to become more professional and demonstrate that they can deliver on the task of improving national security. It is on the basis of this ambition that a measured program of training with U.S. forces might begin.

In any engagement with Indonesian officials, every effort must be made to respect Indonesia's proud tradition of nationalism and independence. Curt threats and public shows of force will be quickly exploited by a small army of extremist propagandists eager to widen the gap between the United States and Indonesia.

The good news in this effort, however, is that responsible Indonesian leaders understand, and understand well, that it is in their best national interest to 
control political extremism (Islamist and others), revive their economy, and continue the professionalization of their armed forces.

Equally significant, the great majority of Muslim leaders share this conviction. They understand well that Islamist extremism intends to destroy not just the United States, but also everything which moderate Muslims hold dear. Certainly, continued or worsening conflict between Israelis and Palestinians will complicate collaboration between the United States and Indonesia. However, we should not confuse Muslim opposition to U.S. assistance to Israel with a deeper clash of cultures. Despite some disagreements, there is no congenital faultline separating Muslim Indonesians from the United States. On the contrary, all evidence from this part of the Muslim world indicates that the tide of modern history is indeed on the side of those who favor higher education, cultural progress, market economies, human decency, and religious tolerance.

More concretely, perhaps, the single most important fact for all parties to remember is that the objective national interests of Indonesia, as well as the objective religious interests of the country's moderate Muslim majority, favor cooperation and friendship with the United States. Inasmuch as this is the case, if U.S.-Indonesian relations are handled diplomatically, progress toward heightened collaboration in educational, economic, and security affairs should be easy and realize immediate mutual benefit. 


\section{CNA}

4825 Mark Center D rive • Alexandria, Virginia 22311-1850 • (703) 824-2000 • www.cna.org 